\title{
Three saprobic Dothideomycetes from the aerial parts of mangrove trees with polyphenism in Striatiguttula
}

\section{Vinit Kumar ( $\nabla$ vinitk56@gmail.com)}

Department of Entomology and Plant Pathology, Faculty of Agriculture, Chiang Mai University, Huay Keaw road, Suthep, Muang District, Chiang Mai, 50200; Center of Excellence in Fungal Research, Mae Fah Luang University, Chiang Rai, 57100 https://orcid.org/0000-0002-3665-8272

\section{Kasun M Thambugala}

Genetics and molecular Biology Unit, Faculty of Applied Sciences, University of Jayewardenepura, Gangodawila, Nugegoda; Department of Plant and Molecular Biology, Faculty of Science, University of Kelaniaya, Kelaniya

\section{Venkatesh Sarma}

Department of Biotechnology, School of Life Sciences, Pondicherry University, kalapet, Puducherry, 605014

\section{R Cheewangkoon}

Department of Entomology and Plant Pathology, Faculty of Agriculture, Chiang Mai University, Huay Keaw Road, Suthep, Muang District, Chiang Mai, 50200

\section{Ting Chi Wen}

State Key Laboratory Breeding Base of Green Pesticide and Agricultural Bioengineering, Key Laboratory of Green Pesticide and Agricultural Bioengineering; The Engineering Research Center of Southwest Bio-Pharmaceutical Resource, Ministry of Education, Guizhou University, Guiyang, 550025

\section{Research Article}

Keywords: 1 new species, 2 new host records, asexual morph, holomorph, Lasiodiplodia, Rhytidhysteron

Posted Date: February 11th, 2021

DOI: https://doi.org/10.21203/rs.3.rs-219757/v1

License: (c) (i) This work is licensed under a Creative Commons Attribution 4.0 International License. Read Full License 


\section{Abstract}

Fungi inhabiting the aerial parts of two mangrove trees, Nypa fruticans, and Rhizophora apiculata, were studied from the central region of Thailand, utilizing morpho-molecular characteristics. Three different fungal taxa were isolated including Rhytidhysteron kirshnacephalus sp. nov., Lasiodiplodia citricola and Striatiguttula phoenicis. Sexual morphs are reported for these three taxa and the asexual morph of Striatiguttula phoenicis is identified based on molecular data. This is the first asexual morph report for the genus Striatiguttula as well as the family Striatiguttulaceae. The new isolate of Striatiguttula phoenicis differs slightly from other extant species in the genus in terms of measurements of ascomata, asci, ascospores, and thickness of peridium. Also, a pigmented hamathecium was observed in this species. The morphological results are congruent to the phylogenetic results of previous studies and support Striatiguttula phoenicis as a new host record from Nypa fruticans. Rhytidhysteron kirshnacephalus was collected from dead twigs of a standing Rhizophora apiculata in Cha-am and it has significant morphological and molecular differences to support its establishment as a novel taxon. Phylogenetically, Rhytidhysteron kirshnacephalus forms a sister clade to Rh. magnoliae, but has different ascomatal characters, including, smooth margins without striations and black pruina.

Lasiodiplodia citricola is another species from Cha-am and a new record from Thai mangroves. Detailed descriptions of the isolates, along with their potential ecological roles, are provided. We have also provided the occurrence of fungi from the aerial parts of mangrove trees worldwide.

\section{Introduction}

Mangroves are salt-tolerant forest ecosystems consisting of woody trees, shrubs, and palms that grow in the intertidal zones of sheltered shores, estuaries, tidal creeks, backwaters, lagoons, marshes, and mudflats of tropical and subtropical coastal regions (Chaeprasert et al. 2010, Thatoi et al. 2013, Hamzah et al. 2018, Kumar et al. 2019a,b). Mangroves are hosts to many fungi, known as manglicolous fungi (Sarma and Hyde 2001, Sarma and Vittal 2001, Vittal and Sarma 2006, Sakayaroj et al. 2011). Mangroves are mainly evergreen forests, productive and rich in nutrients providing organic matter for fungal colonization (Hyde and Lee 1995, Besitulo et al. 2010) as indicated by the variety of species encountered in numerous studies (Hyde 1988a,b, 1990a,b, Sarma and Hyde 2001, 2018, Maria and Sridhar 2003, Sakayaroj et al. 2010, Jones and Abdel-Wahab 2005, Raveendran and Manimohan 2007, Alias and Jones 2009, Isaka et al. 2009, Nambiar and Raveendran 2009, Suetrong et al. 2010, Dayarathne et al. 2017, 2018, Devadatha et al. 2018a,b,c,d, Jones et al. 2019). Previous studies have concentrated on fungi isolated from the intertidal region of the mangrove forests and focused primarily on dead stems, leaves, or bark. However, fungi inhabiting the aerial parts of mangrove trees, such as leaves, branches, stems and aerial roots have rarely been considered in biodiversity studies or surveys (Hyde and Cannon 1992, Dayarathne et al. 2017, 2018, Devadatha et al. 2018a,b,c,d, Sarma 2018, Kumar et al. 2019b). These aerial parts form a separate niche for fungi in mangroves that are different from marine fungi occurring in the submerged parts. Studies have shown that aerial parts harbor diverse fungi and they are considered as terrestrial fungi. For instance, Chi et al. (2019) isolated 203 endophytic fungi from leaves of mangrove forests of Taiwan. In another study, Kumar et al. (2018, 2019a,b) isolated fungal taxa from the aerial parts of the mangrove trees Nypa fruticans and Rhizophora apiculata, which included the asexual morphs of Akanthomyces muscarius and Neopestalotiopsis alpapicalis and the sexual morph of Rhytidhysteron mangrovei.

In Thailand, mangrove forests populate the southern and central coastal regions, where trees from Arecaceae (Nypa fruticans) and Rhizophoraceae, are the most abundant (Bamroongrugsa et al. 2013, Kumar et al. 2018, 2019b, Zhang et al. 2019). Nypa fruticans is an ancient palm that grows in the upper zone of mangroves stretching from the brackish water zone at river mouths to almost inland freshwater (Rozainah and Aslezaeim 2010, Kumar et al. 2018). In a biodiversity study of fungi on N. fruticans, Loilong et al. (2012) reported 139 taxa from Southeast Asian countries, including Brunei, Malaysia, Philippines, Papua New Guinea, and Thailand. Most of the data included fungi reported from decomposing substrates in the intertidal zones. Recently, Sarma and Hyde (2018) listed 46 fungal species from decomposing frond and leaf samples of $N$. fruticans from Brunei, comprising 33 ascomycetes and 13 anamorphic taxa. In another study, fungi found from terrestrial habitats have also been recorded from the aerial and intertidal parts of $N$. fruticans, such as Fasciatispora petrakii, Astrosphaeriella nipicola, Oxydothis nypicola (Hyde and Alias 1999, 2000, Poonyth et al. 2000, Kumar et al. 2018). Rhizophora sp., another mangrove host genus growing in the same zone as $N$. fruticans, harbored a huge number of marine fungi including both saprobes and endophytes (Kohlmeyer 1979, Sarma and Vittal 2001, Schmit and Shearer 2003, Pang et al. 2010, Sakayaroj et al. 2011, Manimohan et al. 2011, Hamzah et al. 2018, Kumar 
et al. 2019a,b). Regardless of these studies, still, the species diversity and proper classification of fungi from $N$. fruticans and other mangrove trees are yet to be fully explored. This is more so from the aerial parts of these two mangroves.

Most fungi reported from mangrove hosts belong to Ascomycota (Dayarathne et al. 2020). Among them, studies on marine Dothideomycetes have increased exponentially in recent years (Suetrong et al. 2009, Pang et al. 2013, Loganathachetti et al. 2017, Devadatha et al., 2018a,b,c,2019, Kumar et al. 2019b, Zhang et al. 2019, Jones et al. 2019). These have shown that marine Dothideomycetes occur on a wide range of substrata, including mangrove wood, twigs, and leaves, sea and marsh grasses (Kohlmeyer et al. 1995, 1996, 1997, Suetrong et al. 2009, Kumar et al. 2019b, Zhang et al. 2019). Liu et al. (2017) listed 28 Dothideomycete clades, of which 18 have marine representatives (Jones et al. 2019). New mangrove sites studied in recent times show several new genera and species belonging to Dothideomycetes being recorded and it indicates that there is still a huge hidden diversity to be explored (Devadatha et al., 2017, 2018a,b,c,d, Jones et al., 2019, 2020).

During surveys of fungal species associated with the aerial parts of mangrove plants, Nypa fruticans, and Rhizophora apiculata, conducted in central and southern Thailand, three fungal species were recorded representing different orders of Dothideomycetes viz. Pleosporales, Hysteriales, and Botryosphaeriales. We introduce one new species Rhytidhysteron kirshnacephalus sp. nov., by comparing its morphology with existing Rhytidhysteron species and providing phylogenetic studies using LSU, ITS, and TEF markers. Two new host records for Lasiodiplodia citricola and Striatiguttula phoenicis are also introduced. An updated list of fungi occurring in the aerial parts of mangrove trees is lacking. Hence, we have provided a list of fungal diversity from the aerial parts of mangrove trees worldwide.

\section{Materials And Methods Collection and Isolation}

Dead twigs of standing Rhizophoraapiculata tree were collected from Cha-am District, Phetchaburi Province in Southern Thailand $\left(12^{\circ} 48^{\prime} 54.8^{\prime \prime} \mathrm{N} 99^{\circ} 58^{\prime} 54.3^{\prime \prime} \mathrm{E}\right)$. Dead rachides or leaflets of Nypa fruticans were collected from Samut Songkhram Province in Central Thailand $\left(13^{\circ} 21^{\prime} 46.9^{\prime \prime} \mathrm{N} 99^{\circ} 59^{\prime} 43.1^{\prime \prime} \mathrm{E}\right)$. Fungi were isolated on potato dextrose agar (PDA) using single spore isolation method as described by Chomnunti et al. (2014). Germinating spores were transferred aseptically to fresh PDA plates and incubated at $27^{\circ} \mathrm{C} \pm 2{ }^{\circ} \mathrm{C}$ for $7-14$ days to establish pure cultures. Morphological characteristics, such as mycelium color, shape, texture, and growth rate were recorded. Cultures were deposited in Mae Fah Luang University Culture Collection (MFLUCC). Specimens (dry wood material with the fungal material) were deposited in the herbarium of Mae Fah Luang University (MFLU). Specimens were observed and examined with a Motic SMZ 168 stereomicroscope. Micro-morphological characters of the taxon were examined with Canon EOS 750D and Leica. ImageJ software was used for measurements (Schneider et al. 2012). Faces of fungi numbers are provided as outlined in Jayasiri et al. (2015), and the species has been registered for Index Fungorum numbers (2020).

\section{DNA isolation and amplification}

Total genomic DNA was extracted, following the modified CTAB method, from freshly harvested mycelium (500 mg) (Thambugala et al. 2015, 2016, Zhang et al. 2019). and Zhang et al. (2019). The ITS region was amplified and sequenced with the primers ITS5 and ITS4 (White et al. 1990), the LSU was amplified using primers LROR and LR5 (Vilgalys and Hester 1990, Rehner and Samuels 1994), NS1 and NS4 were used for SSU (White et al. 1990) and the TEF gene region was amplified using primers EF1-983F and EF1-2218R (Rehner and Buckley 2005). The PCR reactions were performed in a total volume of $25 \mu$ l. PCR mixtures contained 0.3 $\mu \mathrm{l}$ of TaKaRa Ex-Taq DNA polymerase, $12.5 \mu \mathrm{l}$ of $2 \times$ PCR buffer with $2.5 \mu \mathrm{l}$ of dNTPs, $1 \mu \mathrm{l}$ of each primer, $9.2 \mu$ l of double-distilled water, and 100-150 ng/ $\mu$ l of DNA template. PCR reactions were run on a BIORAD 1000 Thermal Cycler (Applied Biosystems, Foster City, CA, U.S.A.) using the conditions described by Thambugala et al. (2015) and Zhang et al. (2019). The sequencing of the positive amplicons with primers used in the amplification reaction was carried out by Sun-biotech Company Sequencer (Beijing, China).

\section{Phylogenetic analysis}


Consensus sequences were obtained by combining forward and reverse directions, using CLC Main Workbench sequence analysis software v.6.0.2 (CLC bio, Cambridge, MA). Newly generated sequences were analyzed along with reference sequences from GenBank and those derived from Zhang et al. (2019), Thambugala et al. (2016), and Jayawardena et al. (2019) (Table 1, 2, 5). Sequence alignments were prepared with MAFFT v.6.864b (Katoh and Standley 2013: http://mafft.cbrc.jp/alignment/server/) and manually aligned, wherever necessary using BioEdit v.7.2.3 (Hall 1999). The sequence datasets were combined using BioEdit v.7.2.3 and CLC Main Workbench version 6.0.2. The evolutionary models for both Bayesian inference and maximum likelihood analyses were selected independently for each locus using MrModeltest v. 2.3 (Nylander 2004) under the Akaike Information Criterion (AIC) implemented in PAUP v. 4.0b10. The GTRGAMMA model of nucleotide evolution was the best-fit model for all loci. All phylogenetic analyses were performed in the CIPRES Science Gateway v.3.3 (http://www.phylo.org/ portal2/, Miller et al. 2010). Maximum likelihood (ML) trees were inferred using RAxML v.8.2.8 as part of the "RAxML- HPC2 on XSEDE" tool (Stamatakis 2006, 2008). The maximum likelihood bootstrap support was calculated from 1000 bootstrap replicates (Fig.3, 5, 7). Bayesian inference (BI) analysis was conducted using the Markov Chain Monte Carlo (MCMC) algorithm as implemented in MrBayes v. 3.2.2 (Ronquist et al. 2011). Ten (for Striatiguttula) and five (for Rhytidhysteron; Lasiodiplodia) million generations were run with a sampling frequency every $1000^{\text {th }}$ generation. Twenty-five percent of the trees were discarded as "burn-in". Convergence was declared when the standard deviation of split frequencies reached 0.01. Phylogenetic trees were visualized using Fig Tree v1.4.0 (http://tree.bio. ed.ac.uk/software/fgtree/, Rambaut 2012). All newly generated sequences were deposited in GenBank (Table 1, 2, 5).

\section{Results}

\section{Phylogenetic analysis}

Phylogenetic analyses were performed using combined datasets as follows: in the case of Striatiguttula, after alignment the combined LSU, SSU, and TEF gene dataset consisted 110 taxa including Arthonia dispersa (UPSC2583), Dendrographa decolorans (Ertz 5003) (BR), Lecanactis abietina (Ertz 5068) (BR), and Roccella fuciformis (Tehler 8171) as outgroup taxa (Zhang et al. 2019). Following trimming, the combined alignment length was 2764 bps, whereby LSU contained 852 sites, SSU had 1011 sites and TEF had 901 sites. The likelihood value of the best-scoring ML tree (Fig. 3) was -28841.595208. The matrix had 1275 distinct alignment patterns, with $30.95 \%$ being undetermined characters or gaps. Outgroup sequences formed a monophyletic clade that had maximum support (BS100\%/1.0BI). All Striatiguttulaceae sequences grouped together (BS80\%/0.97BI). Two sequences from the new isolate SS16-2 grouped with S. phoenicis (MFLUCC 18-0266; Fig. 3) with maximum support (BS100\%/1.0BI).

A combined LSU, ITS, and TEF dataset was used for the phylogenetic analysis of Rhytidhysteron strains. The dataset contained 28 taxa of Rhytidhysteron with Gloniopsis praelonga (CBS 112415) being the outgroup taxon. After trimming, the alignment had 2420 characters, whereby LSU contained 788 sites, ITS had 640 sites and TEF had 992 sites. The alignment has 522 distinct alignment patterns with $35.16 \%$ undetermined characters. The RAxML analysis for the combined dataset provided the best scoring tree (Fig. 5) with a final ML optimization likelihood value of -7391.602161 . The new isolate, Rhytidhysteron kirshnacephalus resides in a distinct clade as a sister group to $R h$. mangrovei (BS100\%/1.0BI).

The third phylogenetic analysis contained 43 sequences of Lasiodiplodia including the new host record of Lasiodiplodia citricola (MFLUCC 19-0622) and two outgroup taxa viz. Barriopsis iraniana (IRAN1448C) and B. tectonae (CMW40687) (Table 5). After trimming, the alignment had 772 characters, whereby ITS had 456 sites and TEF had 316 sites. Lasiodiplodia citricola (MFLUCC 19-0622) clustered together with the ex-type strain of L. citricola (IRAN 1522C) in the ML analysis and tree topology in BI was most similar to the type strain (Fig. 7). The likelihood value of the best-scoring ML tree was -3733.342956 (Fig. 7). The matrix had 253 distinct alignment patterns, with $4.41 \%$ being undetermined characters or gaps. The new isolate, L. citricola MFLUCC (19-0622) clustered with L. citricola (IRAN 1522C) with low support (BS59\%/0.63BI).

\section{Taxonomy}

\section{Striatiguttula}

The genus was introduced by Zhang et al. (2019) along with another new genus Longicorpus in Striatiguttulaceae. Striatiguttula is typified by $S$. nypae which was isolated as a saprobic fungus from Nypa fruticans. The genus comprises two species. S. nypae 
and S. phoenicis (Index Fungorum 2019, Zhang et al. 2019).

Striatiguttula phoenicis S.N. Zhang, K.D. Hyde, and J.K. Liu 2019 (Fig. 1,2)

Index Fungorum number. 828275; Facesoffungi number. FoF 05035

Saprobic on the midrib of Nypa fruticans Wurmb. leaflet. Sexual morph: Ascomata in vertical section 250-380 $\mu \mathrm{m}$ high, 195-310 $\mu \mathrm{m}$ diam ( $\overline{\mathrm{x}}=360 \times 306 \mu \mathrm{m}, \mathrm{n}=10)$, black, scattered, immersed and erumpent through host epidermis by a papilla or a short neck, ampulliform, subglobose, uni-loculate, coriaceous to carbonaceous, ostiolate, periphysate, papillate, glabrous neck. Peridium 30$90(\overline{\mathrm{x}}=66, \mathrm{n}=10) \mu \mathrm{m}$ thick, composed of several pale brown to hyaline cells of textura angularis, compressed and pallid inwardly. Wall of the neck composed of thick and elongated angular pale brown to brown cells with hyaline inner layers. Hamathecium of 1.75-2.5 ( $\overline{\mathrm{x}}=1.92 \mu \mathrm{m}, \mathrm{n}=20) \mu \mathrm{m}$ wide, septate, branched, filamentous, anastomosing, trabeculate pseudoparaphyses, embedded in a gelatinous matrix, pigmented (purple). Asci 64-128 $\times 9-13.8 \mu \mathrm{m},(\overline{\mathrm{x}}=90.4 \times 11.8 \mu \mathrm{m}, \mathrm{n}=20), 8$-spored, bitunicate, fissitunicate, cylindric clavate, pedicellate, apically rounded, with an ocular chamber. Ascospores 13-39 $\times 6.4-8 \mu \mathrm{m},(\overline{\mathrm{x}}=27 \times 7.2$ $\mu \mathrm{m}, \mathrm{n}=30$ ), thick-walled, hyaline to light-brown, uniseriate to biseriate, fusiform to ellipsoidal, $0-3$-septate, constricted at the central septum, the upper-middle cell slightly swollen and larger, straight or slightly curved, striate, guttulate, surrounded by an irregular mucilaginous sheath (1.5-6 $\mu \mathrm{m}$ wide at both ends and 2-8.5 $\mu \mathrm{m}$ wide on the sides). Asexual morph: Conidiomata pycnidial, semi-immersed to immersed, globose, dark, unilocular, thick-walled (dark brown), ostiolate. Conidiomatal wall textura angularis to textura prismatica, 310-353 $\mu \mathrm{m}$ high, 300-330 $\mu \mathrm{m}$ diam ( $\overline{\mathrm{x}}=325 \times 310 \mu \mathrm{m}, \mathrm{n}=5)$, peridium 37-93 $\mu \mathrm{m}$ wide. Conidiophores reduced to conidiogenous cells. Conidiogenous cells holoblastic, cylindrical to ampulliform, hyaline, smooth, thinwalled, septate, single apical conidium, 20-32.3 $\times 4-7.6 \mu \mathrm{m},(\overline{\mathrm{x}}=27.6 \times 5.7 \mu \mathrm{m}, \mathrm{n}=30)$. Conidia hyaline thin-walled, smooth, rarely guttulate, aseptate, oval, $4.5-6.8 \times 4.2-4.5 \mu \mathrm{m},(\overline{\mathrm{x}}=5.5 \times 4.3 \mu \mathrm{m}, \mathrm{n}=40)$.

Material examined: Thailand, Samut Songkhram Province, on a dead midrib of the leaflet of Nypa fruticans (Arecaceae), 11 June 2018, V. Kumar SS16-2 (MFLU 19-2847), living culture, MFLUCC 20-0093.

GenBank. LSU = MT587580, SSU = MT587572, TEF = MT597402

Notes: Members of Striatiguttulaceae are characterized by having immersed to erumpent or superficial ascomata, with a papilla or a short to long neck, ampulliform, subglobose or conical, trabeculate pseudoparaphyses, cylindric-clavate, bitunicate asci, and hyaline to brown, uniseriate to biseriate, fusiform to ellipsoidal, striate and 1-3-septate ascospores. Most morphological observations between the sexual morphs of Striatiguttula species are closely related (Zhang et al. 2019, Table 3). Both the sexual and asexual morphs of Striatiguttula phoenicis (MFLU 19-2847; MFLUCC 20-0093 and MFLUCC 20-0094) were observed on the same substrate within two months. The asexual morph was observed before the sexual morph (Fig. 1,2). The sexual morph of the new isolate has notable morphological differences compared to the holotype of $S$. phoenicis (MFLUCC 18-0266), such as the size of the ascomata (250-380 × 195-310 vs. 195-580 × 135-390), the width of the peridium (30-90 vs. 10-24), size of the asci (64-128 $\times 9-13.8$ vs. 89-141 × 12-18), shape and size the ascospore (ellipsoidal to fusiform, $13-32 \times 6.4-8$ vs. fusiform to ellipsoidal, 20-29 $\times$ 6-10) (Zhang et al. 2019). However, the asexual morph has overlapping characters with other asexual taxa in Pleosporales (genera in Lophiostomataceae, Lentitheciaceae, Massarinaceae, Morosphaeriaceae, Parabambusicolaceae Tanaka et al. 2015, Hashimoto et al. 2018).

Following suggestions from Li et al. (2015), we used DNA sequence analysis and phylogenetic studies to confirm the establishment of this asexual and sexual morph connection (Fig. 3). Phylogenetic analysis revealed that the new isolate groups with S. phoenicis (MFLUCC 18-0266) with maximum statistical support (100\% BS/ 1.0BI). There are $0.88 \%$ base-pair (8bp out of 912 bp) differences between S. phoenicis (MFLUCC 18-0266) and the S. phoenicis (20-0093/20-0094) from this study in the TEF gene region. When comparing the ITS sequences of our isolate with S. phoenicis MFLUCC 18-0266 (MK035972.1) the identity was relatively high (98.96\%) with having $5(1.04 \%)$ bp differences. Hence, despite having some morphological differences, there is a huge similarity between the molecular data (TEF and ITS genes), based on the recommendations provided by Jeewon and Hyde (2016), here we introduce our collection (MFLU 19-2847) as a new host record for S. phoenicis.

\section{Rhytidhysteron}


The genus, Rhytidhysteron was introduced by Spegazzini (1881) to accommodate $R h$. brasiliense and $R h$. viride and is typified by Rh. brasiliense (Spegazzini 1881, Silva-Hanlin and Hanlin 1999). The genus includes saprobic to weakly pathogenic fungi that grow on woody plants in terrestrial habitats (Yacharoen et al. 2015, Thambugala et al. 2016, Kumar et al. 2019b, De Silva et al. 2020). Currently, 22 species are accepted in this genus (De Silva et al. 2020).

\section{Rhytidhysteron kirshnacephalus Vin. Kumar \& T.C. Wen sp. nov. (Fig. 4)}

Index Fungorum number. IF557639; Facesoffungi number. FoF 08693

Etymology. Refers to the black color pruina, 'kirshna' = Black (Sanskrit), 'cephalus' = head (Greek).

Saprobic on dead wood of standing a mangrove tree, Rhizophora apiculata Blume. Sexual morph: Ascomata 1.2-1.8 long $\times 0.48-$ 0.75 wide $\times 0.32-0.45 \mathrm{~mm}$ high $(\overline{\mathrm{x}}=1.4 \times 0.62 \times 0.3 \mathrm{~mm}, \mathrm{n}=10)$, apothecioid, crowded to aggregate, superficial to semiimmersed, subiculum, brown-black, with exposed, lenticular to irregular, brown-black disc, folded along the margins, compressed at the apex, smooth-without striations. Exciple 45-90 um wide ( $\overline{\mathrm{x}}=65)$, composed of dark brown to black, thin-walled cells of textura angularis. Hamathecium comprising 1.9-3.6 $\mu \mathrm{m}$ wide, dense, septate pseudoparaphyses, constricted at the septa, hyaline, unbranched and forming a dark epithecium above the asci, at the apex and enclosed in a gelatinous matrix, hymenium turns blue in Melzer's reagent. Asci 72-105 × 7.3-10.5 $\mu \mathrm{m}(\overline{\mathrm{x}}=88.5 \times 8.8, \mathrm{n}=20), 4-6$-spored, bitunicate, cylindrical, short pedicellate, rounded at the apex, with a distinct ocular chamber and J+ apical ring. Ascospores 16.5-22 $\times 6.0-7.5 \mu \mathrm{m}(\overline{\mathrm{x}}=19 \times 7.2, \mathrm{n}=30)$,

uniseriate, slightly overlapping, guttulate, hyaline to lightly pigmented when immature, becoming brown when mature, ellipsoidal to fusiform, straight or curved, rounded to slightly pointed at both ends, (1-)3-septate, guttulate, rough wall, constricted at the septum. Asexual morph: Undetermined.

Material examined: Thailand, Cha-am District, Phetchaburi Province, on dead twigs of Rhizophora apiculata (Rhizophoraceae), 11 January 2018, V. Kumar (MFLU 20-0427, holotype); ibid. (BBH isotype), ex-type living culture (MFLUCC 18-1111).

GenBank. LSU= MT612351, ITS= MT712758, TEF= MT674994

Notes: The new isolate, Rhytidhysteron kirshnacephalus, is a sister species to Rhytidhysteron magnoliae (75\% MLBS/1.0 PP Fig. 5). The isolate is characterized by large, conspicuous ascomata with colored pruina (black), and fits well within the species concept of Rhytidhysteron. However, Rhytidhysteron kirshnacephalus differs in the size of exciple from Rh. magnoliae (45-90 vs. 80-100 $\mu \mathrm{m}$ ), appearance and size of ascomata (smooth-without striations versus ascomata distinct rough-striations, $1.2-1.8 \times$ $0.48-0.75 \times 0.32-0.45 \mathrm{~mm}$ vs. $1.2-2.3 \times 0.54-0.6 \times 0.43-0.55 \mathrm{~mm}$ ), pruina (black vs. dark brown), the apex of hamathecium (purple vs hyaline) and asci (72-105 × 7.3-10.5 vs. 160-200 × 13-15 $\mu \mathrm{m})$ (Fig.4, Table 4). We also observed differences in the

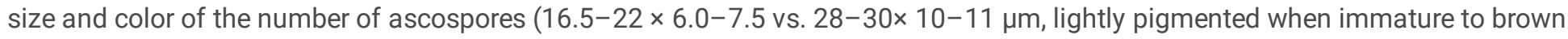
when mature vs. pale brown to dark brown).

The TEF gene has high discriminatory power than rDNA genes, because of the high level of sequence polymorphism among related species (O'Donnell 2000, Mirhendi et al. 2015). Hereby, the observed genetic distance of TEF gene region between $R h$. kirshnacephalus and Rh. magnoliae was $5 \%$ (51 bp), while the LSU differed by $3 \%$ ( $28 \mathrm{bp})$. Finally, the two species differed by $4 \mathrm{bp}$ $(0.6 \%)$ in the ITS region. Based on the observed differences between TEF and LSU data, we establish Rh. kirshnacephalus as a new species following the recommendations laid down by Jeewon and Hyde (2016).

\section{Lasiodiplodia}

This genus comprises 53 species (Dissanayake et al 2017, Hyde et al. 2019), with 66 epithets listed in Index Fungorum (2020). Both sexual and asexual morphs have been reported within the genus (Alves et al. 2008, Tennakoon et al. 2016, Hyde et al. 2019). It is recommended that morphology is unreliable for species differentiation of this genus, but species can be recognized using combined ITS and TEF1-a-asequence data, however, we performed our analysis with ITS only (Phillips et al. 2013, Slippers et al. 2014, Hyde et al. 2019).

Lasiodiplodia citricola Abdollahz., Javadiand A.J.L. Phillips, Persoonia 25: 4 (2010) (Fig. 6) 
Index Fungorum number. IF516777; Facesoffungi number. FoF 05084

Saprobic on dead twigs of Rhizophora apiculata Blume. Asexual morph Conidiomata stromatic, pycnidial, immersed, dark brown to black, covered with dense mycelium, mostly multi-loculate, up to $2 \mathrm{~mm}$ diam, solitary, $270-515 \times 230-432 \mu \mathrm{m}(\overline{\mathrm{x}}=377 \times 300, \mathrm{n}$ $=10$ ), globose, thin-thick-walled, papillate. Conidiomatal wall 4-layered, 90-120 $\mu \mathrm{m}$ wide at the base, $80-110 \mu \mathrm{m}$ wide on sides. Paraphyses flexuous, cylindrical, rough, thin-walled, initially aseptate, becoming up to occasionally 1-2 septate when mature, rounded at apex, occasionally basal, middle or apical cells swollen, $50-80 \mu \mathrm{m}$ long, $3-4 \mu \mathrm{m}$ wide $(\overline{\mathrm{x}}=65 \times 3, \mathrm{n}=30)$.

Conidiophores reduced to conidiogenous cells. Conidiogenous cells holoblastic, discrete, hyaline, rough, thin-walled, ellipsoidalcylindrical, proliferating per-currently with 1-2 annellations, $18-26 \times 3.5-7 \mu \mathrm{m}(\overline{\mathrm{x}}=23 \times 6.5, \mathrm{n}=20)$. Conidia initially hyaline, aseptate, ellipsoid to ovoid, with granular content, both ends broadly rounded, wall thick, $1.5-2.8 \mu \mathrm{m}(\overline{\mathrm{x}}=2.5, \mathrm{n}=20)$, becoming pigmented, ovoid, 1-septate with longitudinal striations, $19-26 \times 11-14 \mu \mathrm{m}(\overline{\mathrm{x}}=24 \times 12, \mathrm{n}=20)$. Sexual morph: undetermined.

Material examined: Thailand, Cha-am Province, on dead twigs of Rhizophora apiculata Blume (Rhizophoraceae) 11 January 2018, Vin. Kumar, KC12b (MFLU 19-0622), living culture (MFLUCC 18-1115).

\section{GenBank. ITS: MK106111}

Notes: Lasiodiplodia, currently comprises 53 species. Both sexual and asexual morphs have been reported within the genus. The genus is a member of the family Botryosphaeriaceae, which is well-known and widespread as plant pathogens occurring mostly in tropical and subtropical regions (Punithalingam 1980). Cruywagen et al. (2017) suggested that hybridization between Lasiodiplodia species is widespread and further suggested that some of the currently recognized species may be hybrids, e.g., $L$. viticola, L. missouriana, L. laeliocattletae, and L. brasiliense. The fungal isolate understudy was obtained from a twig of a mangrove shrub and has been identified as a new host record for L. citricola with support from both morphology and phylogenic data (Fig. 7). This isolate clustered with type strain in the present multi-locus phylogeny (Fig. 7). Morphologically the species is slightly different from the ex-type species, L. citricola (IRAN 1522C) by having rough conidiogenous cells and smaller aseptate paraphyses. In L. citricola (IRAN 1522C), paraphyses are 125 $\mu \mathrm{m}$ long, whereas, in L. citricola (MFLUCC 19-0622), paraphyses are 50-80 $\mu \mathrm{m}$ long, which might have occurred due to the change in the host and environment. While the conidial characters were overlapping for both the species. The untrimmed sequence of ITS had 6 bp differences when compared with that of L. citricola (extype IRAN 1522C and MFLUCC 19-0622). Based on its occurrence, the similarity in morphology, and inadequate differences in the molecular data, here we consider our isolate as a new host record for Lasiodiplodia citricola.

\section{Diversity of fungi on the aerial parts of mangrove trees worldwide}

A list of fungi recorded from the aerial parts of the mangrove trees throughout the world is provided in Table 6 . The occurrence of endophytic, pathogenic, and saprobic fungi from the aerial parts indicates their multi-level and variable relations with the host and their lifestyle. We have documented 268 fungi found on the aerial parts of 46 mangrove trees (Table 6).

Previous studies were mainly conducted in limited countries by different groups, which include Brazil, Brunei, India, Malaysia, Pakistan, Philippines, South Africa, Taiwan, and Thailand. Here we have listed out fungi from 44 different countries and regions, including Australia, Bermuda, Brazil, Brunei, Burma, Cuba, Dominican Republic, French Polynesia, Grenada, Hawaii, Hong Kong, India, Indonesia, Japan, Kenya, Madagascar, Malaysia, Mauritius, Mexico, New Guinea, Pakistan, Panama, Papua New Guinea, Philippines, Portugal, Puerto Rico, Puerto Rico, Puerto Rico, Republic of Formosa, Reunion, Sierra Leone, Singapore, Somalia, South Africa, Sri Lanka, Tahiti, Taiwan, Tanzania, Thailand, USA, Venezuela, West Africa, Zambia, Zanzibar. Among these India, Taiwan, and Thailand have the highest number of fungi from the aerial parts $(79,41$, and 18 , respectively, Table 6$)$. A higher diversity on these mangrove hosts consists of fungi occurring in or on the leaves than branches and roots. In our data, fungi from the genus Aspergillus and Pestalotiod group were very common and have a wide distribution. Based on our data, we reckon that the fungal diversity from the aerial parts of the mangrove forests warrants a systematic survey for a correct estimation.

\section{Discussion}

In this study, three saprobic fungal species were isolated and identified from the aerial parts of mangrove trees, Nypa fruiticans, and Rhizophora apiculata, collected from two different provinces of Central Thailand, Cha-am (Phetchaburi) and Samut 
Songkhram. New isolates were identified by utilizing morpho-molecular techniques. They are as Striatiguttula phoenicis, Rhytidhysteron Kirshnacephalus sp. nov., and Lasiodiplodia citricola

The three isolates belong to the class Dothediomycetes and fall within different orders viz. Pleosporales, Hysteriales, and Botryosphaeriales. The first isolate, Striatiguttula phoenicis, falls in a newly circumscribed family Striatiguttulaceae. The second isolate, Rhytidhysteron kirshnacephalus sp. nov. is a member of Hysteriaceae and is characterized by its large, conspicuous ascomata. The third isolate belongs to the family Botryosphaeriaceae, and is a known pathogen, Lasiodiplodia citricola.

Pleosporales is the largest order within Dothideomycetes with 91 families, of which, 37 have marine representatives (Jones et al. 2019, Brahmanage et al. 2020). Within the 37 families, Striatiguttulaceae was introduced by Zhang et al. (2019) to accommodate species of Longicorpus and Striatiguttula from mangrove substrates. Currently, there are three species in the family: Striatiguttula nypae, S. phoenicis, and Longicorpus striataspora (Zhang et al. 2019). Striatiguttula is the type genus and is characterized by having immersed, erumpent to superficial stromata, with a papilla or a short to a long neck, trabeculate pseudoparaphyses, bitunicate asci, and hyaline to brown, fusiform to ellipsoidal, striate, guttulate, 1-3-septate ascospores, with paler end cells and surrounded by a mucilaginous sheath (Zhang et al. 2019).

The new strain of Striatiguttula phoenicis in this study was isolated from the midrib of the leaflet of $N$. fruticans collected from Samut Songkhram. Morphologically our strain fits well within the species concept of Striatiguttula (Zhang et al. 2019). Previously, S. phoenicis was reported from Phoenix paludosa, which is known to be associated with mangroves and grows on the upper regions of mangrove forests (Teo et al. 2010, Zhang et al. 2019). In our study of fungi from aerial parts of mangrove trees, we isolated $S$. phoenicis from the midrib of a dead leaf from a standing $N$. fruticans in central Thailand. The present report extends the host range of this taxon. Since, in Zhang et al. (2019), the species was isolated from the submerged decaying rachis of $P$. paludosa in Southern Thailand. This suggests that $S$. phoenicis is not limited to one host species perhaps suggesting host jumping in the Arecaceae family though more extensive studies on coevolution are needed. In our isolate, there are slight morphological differences with S. phoenicis (MFLUCC 18-0266) viz. ascomatal size, the thickness of peridium, size of the asci, and size and septation of the ascospore (Fig. 1, Table 3). These morphological differences could be due to the occurrence on a different host plant i.e., N. fruticans. Through this study, we establish the anamorph to teleomorph connection for S. phoenicis through morphological and molecular studies. This is the first report of an anamorph connection reported in the family Striatiguttulaceae (Fig. 2,3). During our study, we observed the asexual morph at first then the sexual morph on the same substrate. This could indicate that $S$. phoenicis reproduces more frequently through the asexual mode of life than through sexual mode (Hyde et al. 2011, Jones et al. 2014).

Rhytidhysteron kirshnacephalus (MFLUCC 18-1111) was collected from the mangroves of Cha-am district, Thailand. It belongs to Hysteriales, which contains only one family, Hysteriaceae. There are three genera of marine or marine-derived fungi in the family: Gloniella, Hysterium, and Rhytidhysteron (Wijayaward. 2017, Jones et al. 2019, Kumar et al. 2019b). Rhytidhysteron was introduced by Spegazzini (1881) and is characterized by large, conspicuous ascomata, usually elongate and boat-shaped and features a prominent, perpendicularly striate margin, in combination with pigmented, sparsely septate to sub-muriform ascospores (Spegazzini 1881, Silva-Hanlin and Hanlin 1999, Thambugala et al. 2016, Kumar et al. 2019b). In the phylogenetic analysis, our isolate (MFLUCC 18-1111) was grouped with Rh. magnoliae as a sister taxon and the two can be separated based on the morphological differences, such as appearance and size of exciple, ascomata, pruina, hamathecium. In addition to the morphological differences, we have also observed DNA base-pair differences (5\% in TEF from Rh. magnoliae) to establish Rhytidhysteron kirshnacephalus (MFLUCC 18-1111) as a new species in the genus (Table 4, Fig. 4,5). Although species of Rhytidhysteron are widely distributed in tropical and temperate countries such as Brazil, France, Ghana, Kenya, most of them have also been found in Thailand (Thambugala et al. 2016, Kumar et al. 2019b). This is not surprising given its tropical climate and mangrove forests, Thailand has one of the rich diversities of Rhytidhysteron. Rhytidhysteron mangrovei and Rh.bruguierae have also been reported from mangroves. Members belonging to Hysteriales are often reported from mangrove habitats, particularly the aerial parts of the mangrove plant substrate (Devadatha et al. 2018, Kumar et al. 2019b, Dayarathne et al. 2020). The superficial, well-protected wall layers of the ascomata of hysteriales seem to protect from desiccation and solar radiation for their occurrence in the upper parts of the mangrove plants. 
Lasiodiplodia citricola (MFLUCC 19-0622) was also found in Cha-am district as a new host record from Rhizophora apiculata. It belongs to Botryosphaeriales, which has nine families. Marine species have been found only in Botryosphaeriaceae and Phyllostictaceae, which belong to Botryosphaeriales (Wijayaward. 2017, Jones et al. 2019, Hyde et al. 2019). Lasiodiplodia was introduced by Ellis and Everh (1896) and is characterized by the presence of pycnidial conidiomata and longitudinal striations on mature conidia (Sutton 1980, Zhou and Stanosz 2001, Slippers et al. 2004, Phillips et al. 2008, 2013, Prasher and Singh 2014, Hyde et al. 2019). Lasiodiplodia citricola seems to be a cosmopolitan fungus, having a broad range of hosts and wide geographic distribution viz. Citrus latifolia, (Mexico), Citrus sp. (Iran), Juglans regia (California), Pistacia vera (California), Prunus persica (California), and Vitis vinifera (Australia, Italy) (USDA, https://nt.ars-grin.gov/fungaldatabases/). Mostly, L. citricola is known as a pathogenic fungus, but the new strain was observed as a saprobe on dead twigs of the mangrove tree, indicating the ability of $L$. citricola to adapt to the occurrence on new hosts and diverse lifestyles with saprophytism recorded in the present study. In our phylogenetic analyses, the TEF sequence of the new host record was not included as we were not successful in obtaining it.

The aerial parts of the mangrove trees in the marine environment are excellent habitat to study fungal diversity and ecology. However, when compared with the fungi from submerged marine/intertidal substrates, the number of fungi from the aerial parts is very small (Jones et al. 2019, Table 6). Poonyth et al. (2000) listed 163 fungi from mangrove and mangrove-associated trees. Whereas here we have listed 268 fungi (from 156 genera) from the aerial parts of 46 mangrove trees across 44 different locations (Table 6). Among them, Aspergillus (15), Pseudocercospora (13), and Pestalotiod fungi (15) are the top three genera to occur on the terrestrial part of the mangrove trees. Based on our data, woody substrata supported a greater number of fungi than leaves and most of them are saprophytes.

This study suggests that future studies should include the examination of fungi found from the aerial parts of mangrove forests and explore their significance. Also, investigations on the underlying mechanism of exhibiting both sexual and asexual morphs and lifestyle switching are required.

\section{Declarations}

Acknowledgments Vinit Kumar is grateful to Prof. Kevin D. Hyde and Prof. EBG Jones for their supervision on the current project; Dr. Eleni Gentekaki, Chanokned Senwanna, and Vinodhini Thiyagaraja to help with sample collection and the molecular data.

Funding We are grateful to the Thailand Research Fund for supporting collection and research facilities (Grant No. RSA5980068). Also, this work was financed by the Science and Technology Foundation of Guizhou Province (No. [2019]2451-3, No. [2017]57883).

Authors' contributions First author and Dr. Sarma VV conceived the idea to include the table containing data for the fungi from the aerial part; Dr. Kasun Thambugala provided his insights on Rhytidhysteron species and Dothideomycetes group; Vinit Kumar wrote the manuscript with contributions from all other authors including Dr. R Cheewangkoon and Dr. Ting Chi Wen. Dr. Ting Chi Wen provided support with the molecular studies.

Data availability Sequence data have been deposited in GenBank. The new isolate has been registered in Index Fungorum and FaceOfFungi.

Ethics approval and consent to participate Not applicable.

Competing interests The authors declare that they have no competing interests

\section{References}

Alias SA, Jones EB (2009) Marine fungi from mangroves of Malaysia. Institute of Ocean and Earth Sciences, University of Malaya. Alias SA, Jones EG, Torres J (1999) Intertidal fungi from the Philippines, with a description of Acrocordiopsis sphaerica sp. nov. (Ascomycota). Fungal Diversity 2:35-41. 
Alves A, Crous PW, Correia A, Phillips AJ (2008) Morphological and molecular data reveal cryptic speciation in Lasiodiplodia theobromae. Fungal Diversity 28:1-3.

Ananda K, Sridhar KR (2002) Diversity of endophytic fungi in the roots of mangrove species on the west coast of India. Canadian Journal of Microbiology. 48(10):871-8.

Batista AC, da Silvia Maia H, Fernandes Vital A (1955) Ascomycetidae aliquot novarum (Some new ascomycetes). An Soc Biol Pernambuco 13:72-86.

Berkeley MJ, Broome CE (1871) The Fungi of Ceylon. Journal of the Linnean Society of London Botany. 56:494-567.

Berkeley MJ. Australian Fungi.-II (1881) Received principally from Baron F. von Mueller. Botanical Journal of the Linnean Society 18:383-9.

Besitulo A, Moslem MA, Hyde KD (2010) Occurrence and distribution of fungi in a mangrove forest on Siargao Island, Philippines. Botanica Marina 53(6):535-43.

Bitancourt AA (1937) New species of Sphaceloma on Terminalia and Genipa. Arch Inst biol Def agric anim 8(13).

Boidin J, Gilles G (1991) Basidiomycètes Aphyllophoralesde l'île de la Réunion. XVI: Les genresHyphoderma, Hyphodermopsis, Chrysoderma nov. gen. et Crustoderma. Cryptogamie Mycologie 12:97-132.

Borse BD (1988) Frequency of occurrence of marine fungi from Maharashtra coast, India. NISCAIR-CSIR, India 165-167.

Cash EK (1938) New records of Hawaiian discomycetes. Mycologia 30:97-107.

Castillo Cabello G (1994) A new species of trametes from Papua New Guinea. Mycotaxon 51: 479-482.

Chaeprasert S, Piapukiew J, Whalley AJ, Sihanonth P (2010) Endophytic fungi from mangrove plant species of Thailand: their antimicrobial and anticancer potentials. Botanica Marina 53(6):555-64.

Chi WC, Chen W, He CC, Guo SY, Cha HJ, Tsang LM, Ho TW, Pang KL (2019) A highly diverse fungal community associated with leaves of the mangrove plant Acanthus ilicifolius var. xiamenensis revealed by isolation and metabarcoding analyses. PeerJ. 7:e7293.

Chomnunti P, Hongsanan S, Aguirre-Hudson B, Tian Q, Peršoh D, Dhami MK, Alias AS, Xu J, Liu X, Stadler M, Hyde KD (2014) The sooty moulds. Fungal Diversity 66(1):1-36.

Chowdhery HJ, Rai JN (1980) Microfungi from mangrove swamps of West Bengal, India. II. Some new records of aquatic fungi. Nova Hedwigia 32:237-242.

Chupp, C. (1954). A Monograph of the Fungus Genus Cercospora. 1-667.

Ciferri R (1954) Meliolae of Santo Domingo (WI). Mycopathologia et mycologia applicate 7(1-2):81-211.

Ciferri R, Gonzalez Fragoso R (1926) Hongos parasitos y saprófitos de la República Dominicana (7a serie). Boletín de la Real Sociedad Española de Historia Natural 26:470-480.

Ciferri R, Gonzalez Fragoso R (1928) Hongos parasitos y saprófitos de la República Dominicana (13 \& 14a serie). Boletín de la Real Sociedad Española de Historia Natural 28:131-144.

Clendenin I (1896) Lasiodiplodia Ellis and Everh. n. gen. Botanical Gazette Crawfordsville 21:92-93.

Cooke MC (1876) Some Indian fungi. Grevillea. 4:114-8.

Corner EH (1991) Ad Polyporaceas VII: the xanthochroic polypores. Beihefte zur Nova Hedwigia 101:177.

Page $10 / 45$ 
Costa IP, Maia LC, Cavalcanti MA (2012) Diversity of leaf endophytic fungi in mangrove plants of northeast Brazil. Brazilian Journal of Microbiology. 43(3):1165-73.

Creager DB (1962) A new Cercospora on Rhizophora mangle. Mycologia 54(5):536-9.

Cruywagen EM, Slippers B, Roux J, Wingfield MJ (2017) Phylogenetic species recognition and hybridisation in Lasiodiplodia: a case study on species from baobabs. Fungal biology. 121(4):420-36.

Dayarathne MC, Jones EB, Maharachchikumbura SS, Devadatha B, Sarma VV, Khongphinitbunjong K, Chomnunti P, Hyde KD (2020) Morpho-molecular characterization of microfungi associated with marine based habitats. Mycosphere 11(1):1-88.

Dayarathne MC, Wanasinghe DN, Jones EG, Chomnunti P, Hyde KD (2018) A novel marine genus, Halobyssothecium (Lentitheciaceae) and epitypification of Halobyssothecium obiones comb. nov. Mycological Progress 17(10):1161-71.

Deighton FC (1976) Studies on Cercospora and allied genera. VI. Pseudocercospora Speg., Pantospora Cif. and Cercoseptoria Petr. Mycological Papers 140:1-168.

Devadatha B, Mehta N, Wanasinghe DN, Baghela A, Sarma VV (2019) Vittaliana mangrovei, gen. nov., sp. nov. (Phaeosphaeriaceae) from mangroves near Pondicherry (India), based on morphology and multigene phylogeny. Cryptogamie Mycologie 40 (7):117-132.

Devadatha B, Sarma VV (2018) Pontoporeia mangrovei sp. nov, a new marine fungus from an Indian mangrove along with a new geographical and host record of Falciformispora lignatilis. Current Research in Environmental and Applied Mycology 8(2):238-46.

Devadatha B, Sarma VV, Ariyawansa HA, Jones EG (2018) Deniquelata vittalii sp. nov., a novel Indian saprobic marine fungus on Suaeda monoica and two new records of marine fungi from Muthupet mangroves, East coast of India. Mycosphere 9:565-582.

Devadatha B, Sarma VV, Jeewon R, Jones EG (2018) Morosphaeria muthupetensis sp. nov. (Morosphaeriaceae) from India: morphological characterization and multigene phylogenetic inference. Botanica marina 61(4):395-405.

Devadatha B, Sarma VV, Jeewon R, Wanasinghe DN, Hyde KD, Jones EG (2018) Thyridariella, a novel marine fungal genus from India: morphological characterization and phylogeny inferred from multigene DNA sequence analyses. Mycological progress 17(7):791-804.

Dissanayake AJ, Camporesi E, Hyde KD, Yan JY, Li XH (2017) Saprobic Botryosphaeriaceae, including Dothiorella italica sp nov., associated with urban and forest trees in Italy. Mycosphere 8(2):1157-76.

Earle FS (1901) Some fungi from Porto Rico. Muhlenbergia 1:10-17.

Ellis JB, Everhart BM (1895) New species of fungi from various localities. Proceedings of the Academy of Natural Sciences of Philadelphia 1:413-41.

Gilbertson RL, Adaskaveg JE (1993) Studies on wood-rotting basidiomycetes of Hawaii. Mycotaxon 49(1):369-97.

Guerrero JJ, General MA, Serrano JE (2018) Culturable Foliar Fungal Endophytes of Mangrove Species in Bicol Region, Philippines. Philippine Journal of Science. 147(4):563-74.

Hall TA (1999) BioEdit: a user-friendly biological sequence alignment editor and analysis program for Windows 95/98/NT. In Nucleic acids symposium series 41:95-98).

Hamzah TN, Lee SY, Hidayat A, Terhem R, Faridah-Hanum I, Mohamed R (2018) Diversity and characterization of endophytic fungi isolated from the tropical mangrove species, Rhizophora mucronata, and identification of potential antagonists against the soil-borne fungus, Fusarium solani. Frontiers in microbiology. 9:1707.

Hansford CG (1946) The foliicolous ascomycetes, their parasites and associated fungi. Mycological Papers 15:1-240.

Page $11 / 45$ 
Hansford CG (1956, publ. 1957) Tropical fungi. VI. New species and revisions. Sydowia 10:41-100.

Hennings PC (1902) Fungi Javanici novi a cl. Prof. Dr Zimmermann collecti. Hedwigia 41:140-149.

Hennings PC (1902, publ. 1903) Botanische Ergebnisse. Fungi. In Baum, H. [ed.], Kunene-Sambesi-Expedition pp. 155-169.

Hennings PC (1904) Fungi Fluminenses a. cl. E. Ule collecti. Hedwigia 43:78-95.

Hennings PC (1908) Fungi S. Paulenses IV. a cl. Puttemans collecti. Hedwigia 48:1-20.

Ho WH and Hyde KD (1996) Pterosporidium gen. nov. to accommodate two species of Anthostomella from mangrove leaves. Canadian Journal of Botany 74 (11):1826-1829.

Hsieh WH, Goh TK (1990) Cercospora and Similar Fungi from Taiwan. 1-376. Taiwan, Taipei; Maw Chang Book Company. Hyde KD (1988) Observations on the vertical distribution of marine fungi on Rhizophora spp. at Kampong Danau mangrove, Brunei. Asian Mar. Biol 5:77-81.

Hyde KD (1990) A study of the vertical zonation of intertidal fungi on Rhiziphora apiculata at Kampong Kapok mangrove, Brunei. Aquatic botany 36(3):255-62.

Hyde KD, Cannon PF (1992) Polystigma sonneratiae causing leaf spots on the mangrove genus Sonneratia. Australian Systematic Botany 5(4):415-20.

Hyde KD, Lee SY (1995) Ecology of mangrove fungi and their role in nutrient cycling: what gaps occur in our knowledge? Hydrobiologia. 295(1-3):107-18.

Hyde KD, Alias SA (1999) Linocarpon angustatum sp. nov., and Neolinocarpon nypicola sp. nov. from petioles of Nypa fruticans, and a list of fungi from aerial parts of this host. Mycoscience 40(2):145-9.

Hyde KD, Goh TK, Lu BS, Alias SA (1999) Eleven new intertidal fungi from Nypa fruticans. Mycological Research 103(11):1409-22.

Hyde KD, Alias SA (2000) Biodiversity and distribution of fungi associated with decomposing Nypa fruticans. Biodiversity and Conservation. 9(3):393-402.

Hyde KD, Sarma VV (2006) Biodiversity and ecological observations on filamentous fungi of Nypa fruticans along the Tutong River, Brunei. Indian Journal of Marine Sciences. 35:297-307.

Hyde KD, Tennakoon DS, Jeewon R, Bhat DJ, Maharachchikumbura SS, Rossi W, Leonardi M, Lee HB, Mun HY, Houbraken J, Nguyen TT (2019) Fungal diversity notes 1036-1150: taxonomic and phylogenetic contributions on genera and species of fungal taxa. Fungal diversity 96(1):1-242.

Hyde KD. Studies on the tropical marine fungi of Brunei. Botanical Journal of the Linnean Society. 1988 Oct 1;98(2):135-51.

Index Fungorum (2020) Available from: http://www.indexfungorum.org/names/names.asp (accessed August 2020)

Isaka M, Yangchum A, Intamas S, Kocharin K, Jones EG, Kongsaeree P, Prabpai S (2009) Aigialomycins and related polyketide metabolites from the mangrove fungus Aigialus parvus BCC 5311. Tetrahedron. 65(22):4396-403.

Ito S, Imai S (1940) Fungi of the Bonin Islands. V. Transactions Sapporo nat Hist Soc 16:120-38.

Ito T, Nakagiri A (1997) Mycoflora of the rhizospheres of mangrove trees. IFO Reearch Communications 18:40-4.

Jayasiri SC, Hyde KD, Ariyawansa HA, Bhat J, Buyck B, Cai L, Dai YC, Abd-Elsalam KA, Ertz D, Hidayat I, Jeewon R (2015) The Faces of Fungi database: fungal names linked with morphology, phylogeny and human impacts. Fungal diversity 74(1):3-18. 
Jeewon R, Hyde KD (2016) Establishing species boundaries and new taxa among fungi: recommendations to resolve taxonomic ambiguities. Mycosphere 7(11):1669-77.

Jones EG, Abdel-Wahab MA (2005) Marine fungi from the Bahamas Islands. Botanica Marina 48(5-6):356-64.

Jones EG, Devadatha B, Abdel-Wahab MA, Dayarathne MC, Zhang SN, Hyde KD, Liu JK, Bahkali AH, Sarma VV, Tibell S, Tibell L. (2019) Phylogeny of new marine Dothideomycetes and Sordariomycetes from mangroves and deep-sea sediments. Botanica Marina 63(2):155-81.

Jones EG, Pang KL, Abdel-Wahab MA, Scholz B, Hyde KD, Boekhout T, Ebel R, Rateb ME, Henderson L, Sakayaroj J, Suetrong S (2019) An online resource for marine fungi. Fungal Diversity 96(1):347-433.

Kar AK, Mandal M (1969) New Cercospora spp. from West Bengal. Transactions of the British mycological Society 53(3):337-60.

Kar AK, Mandal M (1973) New Cercospora spp. from West Bengal. III. Indian Phytopathology 26(4): 674-680.

Karsten PA, Hariot P (1890) Ascomycetes novi. Revue Mycologique Toulouse 12(48): 169-173.

Katoh K, Standley DM (2013) MAFFT multiple sequence alignment software version 7: improvements in performance and usability. Molecular biology and evolution 30(4):772-80.

Katumoto K, Harada Y (1979) Plant parasitic fungi from the Bonin Islands. II. Ascomycotina and Deuteromycotina. Trans Mycol Soc Japan 20:411-428.

Kobayashi T, Onuki M (1990) Notes on some new or noteworthy fungi parasitic to woody plants from the Yaeyama Islands, Kyushu, Japan. Reports of the Tottori Mycological Ins 28:159-69.

Koehn RD, Garrison RA (1981) Fungi associated with Avicennia germinans from the vicinity of Port Aransas, Texas. Mycologia 73(6):1183-6.

Kohlmeyer J (1969) Ecological notes on fungi in mangrove forests. Transactions of the British Mycological Society 53(2):237IN5.

Kohlmeyer J (1979) Marine fungal pathogens among Ascomycetes and Deuteromycetes. Experientia 35(4):437-9.

Kohlmeyer J, Bebout B, Vlkmann-Kohlmeyer B (1995) Decomposition of mangrove wood by marine fungi and teredinids in Belize. Marine Ecology 16(1):27-39.

Kohlmeyer J, Volkmann-Kohlmeyer B, Eriksson OE (1996) Fungi on Juncus roemerianus. New marine and terrestrial ascomycetes. Mycological Research 100(4):393-404.

Kohlmeyer J, Volkmann-Kohlmeyer B, Eriksson OE (1997) Fungi on Juncus roemerianus. 9. New obligate and facultative marine ascomycotina. Botanica Marina 40:291-300.

Koorders SH (1907) Botanische Untersuchungen über einige in Java vorkommende Pilze, besonders über Blätter bewohnende, parasitisch auftretende Arten. Verhandelingen der Koninklijke Akademie van Vetenschappen te Amsterdam Sect 13 (4): 1-264.

Kumar V, Cheewangkoon R, Gentekaki E, Maharachchikumbura SS, Brahmanage RS, Hyde KD (2019a) Neopestalotiopsis alpapicalis sp. nov. a new endophyte from tropical mangrove trees in Krabi Province (Thailand). Phytotaxa 393(3):251-62.

Kumar V, Cheewangkoon R, Thambugala KM, JONES GE, Brahmanage RS, Doilom M, Jeewon R, Hyde KD (2019b) Rhytidhysteron mangrovei (Hysteriaceae), a new species from mangroves in Phetchaburi Province, Thailand. Phytotaxa 401(3):166-78.

Kumaresan V, Suryanarayanan TS (2001) Occurrence and distribution of endophytic fungi in a mangrove community. Mycological Research. 105(11):1388-91. 
Kumaresan V, Suryanarayanan TS (2002) Endophyte assemblagesin young, mature and senescent leaves ofRhizophora apiculata:evidence for the role of endophytes in mangrove litter degra-dation. Fungal Diversity 9:81-91.

Kumaresan V, Suryanarayanan TS (2001) Occurrence and distribution of endophytic fungi in a mangrove community. Mycological Research 105:1388-1391.

Kuthubutheen AJ (1981) Fungi associated with the aerial parts of Malaysian mangrove plants. Mycopathologia 76(1):33.

Kuthubutheen AJ (1984) Leaf surface fungi associated with Avicennia alba and Rhizophora mucronata in Malaysia. In:

Proceedings of the Asian Symposium on Mangrove Environment- Research and Management, pp 153-171.

Kuthubutheen AJ, Nawawi A (1991) Eight new species of Dictyochaeta (Hyphomycetes) from Malaysia. Mycological Research 95(10):1211-9.

Lee BKH, Baker G E (1972) An ecological study of the soil microfungi in a Hawaiian mangrove swamp. Pacific Science 26:1-10.

Leong WF, Tan TK, Jones EBG (1988) Lignicolous marine fungi of Singapore. Canadian Journal of Botany 66 (11):2167-2170.

Li WJ, Bhat DJ, Camporesi E, Tian Q, Wijayawardene NN, Dai DQ, Phookamsak R, Chomnunti P, Bahkali AH, Hyde KD (2015) New asexual morph taxa in Phaeosphaeriaceae. Mycosphere 6(6):681-708.

Liu JK, Hyde KD, Jeewon R, Phillips AJ, Maharachchikumbura SS, Ryberg M, Liu ZY, Zhao Q (2017) Ranking higher taxa using divergence times: a case study in Dothideomycetes. Fungal Diversity 84(1):75-99.

Loganathachetti DS, Poosakkannu A, Muthuraman S (2017) Fungal community assemblage of different soil compartments in mangrove ecosystem. Scientific reports 7(1):1-9.

Loilong A, Sakayaroj J, Rungjindamai N, Choeyklin R, Jones EG (2012) 15 Biodiversity of fungi on the palm Nypa fruticans. Marine Fungi: and Fungal-like Organisms 31:273.

Luke P, Reddy CN (1979) A new leafspot disease of Thespesia populnea (L.) Soland ex Corr. Current Science 48 (13): $590-591$.

Manimohan P, Amritha M, Sairabanu NK (2011) A comparison of diversity of marine fungi on three co-habiting mangrove plants. Mycosphere 2(5):533-8.

Maria GL, Sridhar KR (2003) Diversity of filamentous fungi on woody litter of five mangrove plant species from the southwest coast of India. Fungal Diversity 14(14):109-26.

McAlpine D (1897) Two additions to the fungi of New South Wales. Proceedings of the Linnean Society of New South Wales 22: 722-724.

Mercado Sierra Á (1984) Nueva especie de Capnobotrys (Hyphomycetes) de la fumagina en Cuba. Acta Botánica Cubana 23: 1-5.

Meyers SP, Orpurt PA, Simms J, Boral LL (1965) Thalassiomycetes VII. Observations on fungal infestation of turtle grass, Thalassia testudinum König. Bulletin of Marine Science 15(3):548-64.

Miller MA, Pfeiffer W, Schwartz T (2012) The CIPRES science gateway: enabling high-impact science for phylogenetics researchers with limited resources. In Proceedings of the $1 \mathrm{st}$ Conference of the Extreme Science and Engineering Discovery Environment: Bridging from the extreme to the campus and beyond 16:1-8.

Murrill WA (1908) Additional Philippine Polyporaceae. Bulletin of the Torrey Botanical Club 35:391-416.

Nambiar GR, Raveendran K (2009) Manglicolous marine fungi on Avicennia and Rhizophora along Kerala coast (India). Middle East J Sci Res 4:48-51. 
Nayak BK, Anandhu R (2017) Biodiversity of Phylloplane and Endophytic Fungi from Different Aged Leaves of Medicinal Mangrove Plant Species, Avicennia marina. Journal of Pharmaceutical Sciences and Research. 9(1):6.

Newell SY (1973) Succession and role of fungi in the degradation of red mangrove seedlings. In: Stevenson LH, Colwell RR (eds) Estuarine microbiol ecology. Univ. of South Carolina Press, Columbia, pp 467-480.

Newell SY (1976) Mangrove fungi: the succession in the mycoflora of red mangrove (Rhisophora mangle L.) seedlings. In: Jones EBG (ed) Recent advances in aquatic mycology. Paul Elek Ltd., London, pp 51-91.

Newell SY, Fell JW (1980) Mycoflora of turtlegrass (Thalassia testudinum Konig) as recorded after seawater incubation. Botanica Marina 23:265-275.

Norphanphoun C, Raspé O, Jeewon R, Wen TC, Hyde KD (2018) Morphological and phylogenetic characterisation of novel Cytospora species associated with mangroves. MycoKeys 38:93.

Norphanphoun C, Jayawardena RS, Chen Y, Wen TC, Meepol W, Hyde KD (2019) Morphological and phylogenetic characterization of novel pestalotioid species associated with mangroves in Thailand. Mycosphere. 10:531-578.

Nylander J (2004) MrModeltest V2. Program Distributed by the Author. Bioinformatics. 24:581-583.

Olive LS (1958) The Lower Basidiomycetes of Tahiti [Continued]. Bulletin of the Torrey Botanical Club. Mar 1;85(2):89-110.

Olive LS (1957) Tulasnellaceae of Tahiti. A revision of the family. Mycologia 49 (5): 663-679.

Osorio JA, Crous CJ, De Beer ZW, Wingfield MJ, Roux J (2017) Endophytic Botryosphaeriaceae, including five new species, associated with mangrove trees in South Africa. Fungal biology 121(4):361-93.

Pang KL, Hyde KD, Alias SA, Suetrong S, Guo SY, Idid R, Jones EG (2013) Dyfrolomycetaceae, a new family in the Dothideomycetes, Ascomycota. Cryptogamie, Mycologie 34(3):223-32.

Pang KL, Sharuddin SS, Alias SA, Nor NA, Awaluddin HH (2010) Diversity and abundance of lignicolous marine fungi from the east and west coasts of Peninsular Malaysia and Sabah (Borneo Island). Botanica Marina 53(6):515-23.

Patouillard N (1916) Une lépiote Africaine des nids de termites (Lepiota letestui). Bulletin Trimestriel de la Société Mycologique de France 32:59-62.

Petch T (1925) Additions to Ceylon fungi. III. Annals of the Royal Botanic Gardens, Peradeniya 9(3):313-328.

Petrak F (1928) Über Englerula und die Englerulaceen. Annales Mycologici 26(5-6):385-413.

Petrak F, Ciferri R (1930) Fungi Dominicani [Dominican fungi]. Annales Mycologici 28 (5-6):377-420.

Petrak F, Ciferri R (1932) Fungi Dominicani. II. Annales Mycologici 30(3-4):149-353.

Phillips AJ, Alves A, Abdollahzadeh J, Slippers B, Wingfield MJ, Groenewald JZ, Crous PW (2013) The Botryosphaeriaceae: genera and species known from culture. Studies in mycology 76:51-167.

Phillips AJ, Alves A, Pennycook SR, Johnston PR, Ramaley A, Akulov A, Crous PW (2008) Resolving the phylogenetic and taxonomic status of dark-spored teleomorph genera in the Botryosphaeriaceae. Persoonia: Molecular Phylogeny and Evolution of Fungi 21:29.

Poon MO, Hyde KD (1998) Biodiversity of intertidal estuarine fungi on Phragmites at Mai Po marshes, Hong Kong. Botanica marina 41:141-155.

Poonyth AD, Hyde KD, Aptroot A, Peerally A (2000) Mauritiana rhizophorae gen. et sp. nov. (Ascomycetes, Requienellaceae), with a list of terrestrial saprobic mangrove fungi. Fungal Diversity 4:101-116. 
Prasher IB, Singh G (2014) Lasiodiplodia indica-A new species of coelomycetous mitosporic fungus from India. Kavaka 43:64-9.

Punithalingam E (1980) Plant diseases attributed to Botryodiplodia theobromae Pat. J. Cramer p121. In: Plant diseases attributed to Botryodiplodia theobromae Pat., pp 123 pp. ref.324.

Raciborski M (1909) Parasitische und epiphytische Pilze Javas. Bulletin de l'Académie des Sciences de Cracovie Classe des Sciences Mathématiques et Naturelles 346-394.

Rai JN Tewari JP Mukerji KG (1969) Mycoflora of mangrove mud. Mycopathologia et Mycologia Applicata 38:17-31.

Rajamani T, Suryanarayanan TS, Murali TS, Thirunavukkarasu N (2018) Distribution and diversity of foliar endophytic fungi in the mangroves of Andaman Islands, India. Fungal ecology. 36:109-16.

Rambaut A (2012) FigTree v.1.4.2: Tree Figure Drawing Tool. Available online at: http://tree.bio.ed.ac.uk/software/figtree (Accessed November 28, 2020).

Rao R (1966) A new species of Tryblidaria from India. Mycopathologia et Mycologia Applicata 28(4):359-360.

Raveendran, K. and Manimohan, Patinjareveettil (2007) Marine Fungi of Kerala, A Preliminary Floristic and Ecological Study. 10.13140/2.1.3699.8084.

Rehm HJ (1901) Beiträge zur Pilzflora von Südamerika. XII. Sphaeriales. Hedwigia 40:100-124.

Rehm HJ (1913). Ascomycetes Philippinenses collecti a clar. C.F. Baker. Philippine Journal of Science Section C, Botany 8(3):181194.

Rehner SA, Buckley E (2005) A Beauveria phylogeny inferred from nuclear ITS and EF1-a sequences: evidence for cryptic diversification and links to Cordyceps teleomorphs. Mycologia 97(1):84-98.

Rehner SA, Samuels GJ (1994) Taxonomy and phylogeny of Gliocladium analysed from nuclear large subunit ribosomal DNA sequences. Mycological Research 98(6):625-34.

Reichardt HW (1870) Fungi, hepaticae et musci frondosi. Kaiserlich-Königlichen Hof-und Staatsdruckerei 1:133-196.

Roane MK (1986) Taxonomy of the genus Endothia. In: Roane, M.K.; Griffin, G.J.; Elkins, J.R. [eds], Chestnut Blight, other Endothia Diseases, and the Genus Endothia. USA, Minnesota, St Paul; American Phytopathological Society, pp 28-39.

Ronquist F, Huelsenbeck J, Teslenko M (2011) Draft MrBayes version 3.2 manual: tutorials and model summaries. Distributed with the software from http://brahms. biology. rochester. edu/software. Html 15:1-05.

Rozainah MZ, Aslezaeim N (2010) A demographic study of a mangrove palm, Nypa fruticans. Scientific Research and Essays 5(24):3896-902.

Saccardo PA (1918) 1. Fungi Singaporenses Bakeriani. 2. Fungi Abellinenses novi. Bollettino dell'Orto Botanico dell R. Università di Napoli 6:39-73.

Sakayaroj J, Preedanon S, Supaphon O, Jones EG, Phongpaichit S (2010) Phylogenetic diversity of endophyte assemblages associated with the tropical seagrass Enhalus acoroides in Thailand. Fungal Diversity 42(1):27-45.

Sakayaroj J, Supaphon O, Jones EG, Phongpaichit S (2011) Diversity of higher marine fungi at Hat Khanom-Mu Ko Thale Tai National Park, Southern Thailand. Songklanakarin Journal of Science and Technology 33(1).

Samuels, G. J. and Müller, E (1980; '1979') Life-history studies of Brazilian ascomycetes 7: Rhytidhysteron rufulum and the genus Eutryblidiella. Sydowia 32: 277-292. 
Sarma VV (2018) Obligate Marine Fungi and Bioremediation. In: Prasad R. (eds) Mycoremediation and Environmental Sustainability. Fungal Biology, Springer Cham, pp. 307-323.

Sarma VV, Hyde KD (2001) A review on frequently occurring fungi in mangroves. Fungal Divers 8:1-34.

Sarma VV, Hyde KD (2018) Fungal species consortia on Nypa fruticans at Brunei. Studies in Fungi 3:19-26.

Sarma VV, Vittal BP (2001) Biodiversity of manglicolous fungi on selected plants in the Godavari and Kirshna deltas, east coast of India. Fungal diversity 6:115-30.

Sawada K (1959) Descriptive catalogue of Taiwan (Formosan) fungi. Part XI. Spec. Publ Coll. Agric. Taiwan Univ 8: 1-268.

Sawada K (1942) Descriptive Catalogue of the Formosan Fungi Part 7. Descriptive Catalogue of the Formosan Fungi Part 7:108128.

Schmit JP, Shearer CA (2003) A checklist of mangrove-associated fungi, their geographical distribution and known host plants. Mycotaxon 85(1):423-77.

Schneider CA, Rasband WS, Eliceiri KW (2012) NIH Image to ImageJ: 25 years of image analysis. Nature methods (7):671-5.

Seymour AB (1929) Host Index of the Fungi of North America. i-xiii, USA, Massachusetts, Cambridge; Harvard University Press 1 732.

Shear CL, Stevens ME, Wilcox MS (1924) Botryosphaeria and Physalospora on currant and apple. Journal of Agricultural Research 28:589-598.

Singer R (1988) Über einige Crepidotaceae. Zeitschrift für Mykologie 54(1):69-72.

Slippers B, Fourie G, Crous PW, Coutinho TA, Wingfield BD, Wingfield MJ (2004) Multiple gene sequences delimit Botryosphaeria australis sp. nov. from B. lutea. Mycologia 96(5):1030-41.

Slippers B, Roux J, Wingfield MJ, Van der Walt FJ, Jami F, Mehl JW, Marais GJ (2014) Confronting the constraints of morphological taxonomy in the Botryosphaeriales. Persoonia: Molecular Phylogeny and Evolution of Fungi 33:155.

Soni KK, Dadwal, VS, Jamaluddin (1983). Three new Sphaeropsidales from India. Current Science 52(12):601-603.

Soto-Medina EA, Lücking R, Torres AM (2018) Nuevos registros de líquenes (Familia Graphidaceae) para Colombia. Biota Colombiana 18(2):30-42.

Stamatakis A (2006) RAxML-VI-HPC: maximum likelihood-based phylogenetic analyses with thousands of taxa and mixed models. Bioinformatics 22(21):2688-90.

Stamatakis A, Hoover P, Rougemont J (2008) A rapid bootstrap algorithm for the RAxML web servers. Systematic biology 57(5):758-71.

Stevens NE (1926) Two species of Physalospora on Citrus and other hosts. Mycologia 18(5):206-17.

Stevens FL (1916) The genus Meliola in Porto Rico. Illinois Biological Monographs 2(4):475-554.

Stevens FL (1920) Dothideaceous and other Porto Rican fungi. Botanical Gazette 69:248-257.

Stevens FL (1928) The Meliolineae. II. Annales Mycologici 26(3-4):165-383.

Subramanian CV (1992) Tretocephala decidua gen. et sp.nov., an interesting new hyphomycete. Cryptogamie Mycologie 13 (1):65-68. 
Suetrong S, Sakayaroj J, Phongpaichit S, Jones EG (2010) Morphological and molecular characteristics of a poorly known marine ascomycete, Manglicola guatemalensis (Jahnulales: Pezizomycotina; Dothideomycetes, Incertae sedis): new lineage of marine ascomycetes. Mycologia 102(1):83-92.

Suetrong S, Schoch CL, Spatafora JW, Kohlmeyer J, Volkmann-Kohlmeyer B, Sakayaroj J, Phongpaichit S, Tanaka K, Hirayama K, Jones EB (2009) Molecular systematics of the marine Dothideomycetes. Studies in Mycology 64:155-73.

Suryanarayanan TS, Kumaresan V, Johnson JA (1998) Foliar fungal endophytes from two species of the mangrove Rhizophora. Canadian Journal of Microbiology. 1003-1006.

Suryanarayanan T, Kumaresan V (2002) Endophytic assemblage in young, mature and senescent leaves of Rhizophora apiculata: evidence for the role of endophytes in mangrove community. Fungal diversity. 9:81-91.

Suryanarayanan TS, Kumaresan V (2000) Endophytic fungi of some halophytes from an estuarine mangrove forest. Mycological Research. 104(12):1465-7.

Sutton BC (1980) The coelomycetes. Fungi imperfecti with pycnidia, acervuli and stromata. Commonwealth Mycological Institute.

Sutton BC (1991) Notes on deuteromycetes. III. Sydowia 43:264-280.

Sydow (1916) Mycotheca Germanica fasc. XXVII - XXVIII. Annales Mycologici 14 (3-4):243-247.

Sydow H, Petrak F (1931) Micromycetes Philippinenses. Series secunda. Annales Mycologici 29(3-4):145-279.

Sydow H, Sydow P (1914) Fungi from northern Palawan. Philippine Journal of Science Section C, Botany 9(2):157-189.

Sydow H, Sydow P, Butler EJ (1916) Fungi Indiae orientalis (pars V). Annales Mycologici 14(3-4):177-220.

Tariq MA, Dawar SH, Mehdi FS (2006) Occurrence of fungi on mangrove plants. Pakistan Journal of Botany. 38(4):1293.

Tassi A (1899) Novae micromycetum species descriptae et iconibus illustratae. VI. Bollettino del Laboratorio Orto Bot. de R. Univ. Siena N.S. 2:139-162.

Tennakoon DS, Phillips AJ, Phookamsak R, Ariyawansa HA, Bahkali AH, Hyde KD. Sexual morph of Lasiodiplodia pseudotheobromae (Botryosphaeriaceae, Botryosphaeriales, Dothideomycetes) from China. Mycosphere 7: 990-1000.

Teo S, Ang WF, Lok AF, Kurukulasuriya BR, Tan HT (2010) The status and distribution of the Nipah Palm, Nypa fruticans Wurmb (Arecaceae), In Singapore. Nat. Singap. 3:45-52.

Thambugala KM, Hyde KD, Eungwanichayapant PD, Romero Al, Liu ZY (2016) Additions to the genus Rhytidhysteron in Hysteriaceae. Cryptogamie, Mycologie 37(1):99-116.

Thambugala KM, Hyde KD, Tanaka K, Tian Q, Wanasinghe DN, Ariyawansa HA, Jayasiri SC, Boonmee S, Camporesi E, Hashimoto A, Hirayama K (2015) Towards a natural classification and backbone tree for Lophiostomataceae, Floricolaceae, and Amorosiaceae fam. nov. Fungal Diversity 74(1):199-266.

Thatoi H, Behera BC, Mishra RR (2013) Ecological role and biotechnological potential of mangrove fungi: a review. Mycology 4(1):54-71.

Thorati M, Mishra JK, Kumar S (2016) Isolation, identification of endophytic Fungi from mangrove roots along the coast of South Andaman Sea, Andaman and Nicobar Islands, India. J Mar Biol Oceanogr 2:2.

Tracy SM, Earle FS (1895) Mississippi fungi. Bulletin. Mississippi Agricultural and Mechanical College Experiment Station 34:80124. 
Viennot-Bourgin G (1963) Micromycetes parasites nouveaux récoltés a Madagascar. Bulletin Trimestriel de la Société Mycologique de France 18(1):96-108.

Vinit K, Doilom M, Wanasinghe DN, Bhat DJ, Brahmanage RS, Jeewon R, Xiao Y, Hyde KD (2018) Phylogenetic placement of Akanthomyces muscarius, a new endophyte record from Nypa fruticans in Thailand. Curr Res Environ Appl Mycol J. 8(3):404-17.

Vittal BP, Sarma VV (2007) Diversity and ecology of fungi on mangroves of Bay of Bengal region-An overview. Indian Journal of Marine Sciences 35:308-317.

White TJ, Bruns T, Lee SJ, Taylor J (1990) Amplification and direct sequencing of fungal ribosomal RNA genes for phylogenetics. PCR protocols: a guide to methods and applications. 18(1):315-22.

Wiehe PO (1949) Wilt of Calophyllum inophyllum L. var. tacamaha (Willd.) R.E.V. caused by Haplographium calophylli sp.nov. in Mauritius. Mycological Papers 29:1-11.

Wijayawardene NN, Hyde KD, Lumbsch HT, Liu JK, Maharachchikumbura SS, Ekanayaka AH, Tian Q, Phookamsak R (2017) Outline of ascomycota. Fungal Diversity 88(1):167-263.

Zhang SN, Hyde KD, Jones EG, Jeewon R, Cheewangkoon R, Liu JK (2019) Striatiguttulaceae, a new pleosporalean family to accommodate Longicorpus and Striatiguttula gen. nov. from palms. MycoKeys. 49:99.

Zhou S, Stanosz GR (2001) Relationships among Botryosphaeria species and associated anamorphic fungi inferred from the analyses of ITS and 5.8 S rDNA sequences. Mycologia 93(3):516-27.

\section{Tables}

Table 1 List of Pleosporalean taxa used in this study along with their GenBank Accession numbers. New sequences are given in bold typeface. $T$ stands for the Type species of each genus. 


\begin{tabular}{|c|c|c|c|c|}
\hline \multirow[t]{2}{*}{ Taxa } & \multirow[t]{2}{*}{ Strain/Culture } & \multicolumn{3}{|c|}{ GenBank Accession numbers } \\
\hline & & LSU & SSU & TEF \\
\hline Acrocordiopsis patilii & BCC28167 & GU479773 & GU479737 & - \\
\hline Acrocordiopsis patiliiT & BCC28166 & GU479772 & GU479736 & - \\
\hline Acuminatispora palmarum & MFLUCC 18-0460 & MH390438 & МH390402 & МH399249 \\
\hline Acuminatispora palmarumT & MFLUCC 18-0264 & МH390437 & МH390401 & МH399248 \\
\hline Aigialus grandisT & BCC18419 & GU479774 & GU479738 & GU479838 \\
\hline Aigialus mangrovei & ВСС33563 & GU479776 & GU479741 & GU479840 \\
\hline Aigialus parvus & BCC 18403 & GU479778 & GU479744 & GU479842 \\
\hline Aigialus rhizophorae & BCC 33572 & GU479780 & GU479745 & GU479844 \\
\hline Alternaria alternata & CBS 916.96 & DQ678082 & DQ678031 & DQ677927 \\
\hline Amniculicola lignicolaT & Ying01 & EF493861 & EF493863 & - \\
\hline Anteaglonium abbreviatum & ANM 925a & GQ221877 & - & GQ221924 \\
\hline Anteaglonium globosum & ANM 925.2 & GQ221879 & - & GQ221925 \\
\hline Antealophiotrema brunneosporumT & CBS 123095 & LC194340 & - & LC194382 \\
\hline Aquasubmersa japonica & KT 2862 & LC061587 & LC061582 & - \\
\hline Aquasubmersa mircensisT & MFLUCC 11-0401 & JX276955 & $J X 276956$ & - \\
\hline Arthonia dispersa & UPSC2583 & AY571381 & AY571379 & - \\
\hline Ascocratera manglicolaT & BCC 09270 & GU479782 & GU479747 & GU479846 \\
\hline Astrosphaeriella fusisporaT & MFLUCC 10-0555 & KT955462 & - & - \\
\hline Astrosphaeriella neofusispora & MFLUCC 11-0161 & KT955463 & KT955444 & - \\
\hline Astrosphaeriella stellata & KT998 & AB524592 & AB524451 & - \\
\hline Astrosphaeriellopsis bakeriana & MFLUCC 11-0027 & JN846730 & - & - \\
\hline Astrosphaeriellopsis bakerianaT & CBS 115556 & GU301801 & - & GU349015 \\
\hline Bimuria novae-zelandiaeT & CBS 107.79 & AY016356 & AY016338 & DQ471087 \\
\hline Botryosphaeria dothidea & CMW 8000 & KF766319 & KF766233 & - \\
\hline Byssothecium circinanst & CBS 675.92 & AY016357 & - & GU349061 \\
\hline Capnodium coffeae & CBS 147.52 & DQ247800 & DQ247808 & DQ471089 \\
\hline Caryospora minima & - & EU196550 & EU196551 & - \\
\hline Caryospora aquatica & MFLUCC 11-0008 & MH057847 & MH057850 & - \\
\hline Cladosporium herbarum & CBS 399.80 & DQ678074 & DQ678022 & DQ677918 \\
\hline Cryptocoryneum condensatum & CBS 122629 & LC194351 & LC194309 & LC096139 \\
\hline Cryptocoryneum pseudorilstonei & CBS 113641 & LC194364 & LC194322 & LC096152 \\
\hline Delitschia chaetomioides & SMH 3253.2 & GU390656 & - & - \\
\hline Delitschia didyma & UME 31411 & DQ384090 & AF242264 & - \\
\hline Delitschia winteri & CBS 225.62 & DQ678077 & - & - \\
\hline
\end{tabular}

Page 20/45 


\begin{tabular}{|c|c|c|c|c|}
\hline Dendrographa decolorans & Ertz 5003 (BR) & NG_027622 & AY548809 & - \\
\hline Didymella exiguaT & CBS 183.55 & EU754155 & EU754056 & - \\
\hline Didymosphaeria rubi-ulmifolii & MFLUCC 14-0023 & KJ436586 & KJ436588 & - \\
\hline Dissoconium aciculare & CBS 204.89 & GU214419 & GU214523 & - \\
\hline Dothidotthia aspera & CPC 12933 & EU673276 & EU673228 & - \\
\hline Dothidotthia symphoricarpiT & CPC 12929 & EU673273 & EU673224 & - \\
\hline Extremus antarcticus & CCFEE 5312 & KF310020 & - & - \\
\hline Fissuroma bambusae & MFLUCC 11-0160 & KT955468 & KT955448 & KT955430 \\
\hline Halotthia posidoniaeT & BBH 22481 & GU479786 & - & - \\
\hline Hermatomyces iriomotensis & MAFF 245730 & LC194367 & - & LC194394 \\
\hline Hypsostroma caimitalense & GKM 1165 & GU385180 & - & - \\
\hline Hypsostroma saxicolat & SMH 5005 & GU385181 & - & - \\
\hline Hysterium angustatum & CBS 236.34 & FJ161180 & GU397359 & FJ161096 \\
\hline Hysterobrevium smilacis & CBS 114601 & FJ161174 & FJ161135 & FJ161091 \\
\hline Latorua caligansT & CBS 576.65 & KR873266 & - & - \\
\hline Latorua grootfonteinensis & CBS 369.72 & KR873267 & - & - \\
\hline Lecanactis abietina & Ertz 5068 (BR) & AY548812 & AY548805 & - \\
\hline Longicorpus striatasporaT & MFLUCC 18-0267 & MK035988 & MK035973 & MK034428 \\
\hline Longicorpus striataspora & MFLUCC 18-0268 & MK035989 & MK035974 & MK034429 \\
\hline Longicorpus striataspora & MFLUCC 17-2515 & MK035990 & MK035975 & MK034430 \\
\hline Longicorpus striataspora & MFLUCC 17-2516 & MK035991 & MK035976 & MK034431 \\
\hline Lepidosphaeria nicotiae & CBS 101341 & DQ678067 & - & - \\
\hline Leptosphaeria doliolumT & CBS 505.75 & GU301827 & GU296159 & GU349069 \\
\hline Leptoxyphium fumago & CBS 123.26 & GU301831 & GU214535 & GU349051 \\
\hline Ligninsphaeria jonesii & GZCC 15-0080 & KU221038 & - & - \\
\hline Ligninsphaeria jonesiiT & MFLUCC 15-0641 & KU221037 & - & - \\
\hline Lindgomyces cinctosporae & R56-1 & AB522431 & AB522430 & - \\
\hline Lindgomyces ingoldianusT & ATCC 200398 & AB521736 & AB521719 & - \\
\hline Lindgomyces rotundatus & KT1096 & AB521740 & AB521723 & - \\
\hline Lophiostoma macrostomoides & GKM1033 & GU385190 & - & - \\
\hline Lophiotrema boreale & CBS 114422 & LC194375 & - & LC194402 \\
\hline Lophiotrema lignicola & CBS 122364 & GU301836 & GU296166 & GU349072 \\
\hline Lophiotrema nuculaT & CBS 627.86 & GU301837 & GU296167 & GU349073 \\
\hline Macrodiplodiopsis desmazieriT & CPC 24971 & KR873272 & - & - \\
\hline Massaria anomia & CBS 591.78 & GU301839 & GU296169 & - \\
\hline Massaria gigantispora & M26 & HQ599397 & HQ599447 & HQ599337 \\
\hline
\end{tabular}

Page 21/45 


\begin{tabular}{|c|c|c|c|c|}
\hline Massaria inquinansT & M19 & HQ599402 & HQ599444 & HQ599342 \\
\hline Massarina eburneaT & CBS 473.64 & GU301840 & GU296170 & GU349040 \\
\hline Mauritiana rhizophoraeT & BCC 28866 & GU371824 & - & GU371817 \\
\hline Melanomma pulvis-pyriust & CBS 124080 & GU456323 & GU456302 & GU456265 \\
\hline Murispora rubicundaT & IFRD 2017 & FJ795507 & GU456308 & - \\
\hline Mycosphaerella graminicola & CBS 292.38 & DQ678084 & DQ678033 & - \\
\hline Neoastrosphaeriella krabiensisT & MFLUCC 11-0025 & JN846729 & JN846739 & - \\
\hline Neodeightonia palmicola & MFLUCC10-0822 & HQ199222 & HQ199223 & - \\
\hline Neotestudina rosatii & CBS 690.82 & DQ384107 & DQ384069 & - \\
\hline Nigrograna mackinnoniiT & CBS 674.75 & GQ387613 & - & - \\
\hline Nigrograna marina & CY 1228 & GQ925848 & - & - \\
\hline Phaeosphaeria oryzaeT & CBS 110110 & GQ387591 & GQ387530 & - \\
\hline Phoma herbarumT & CBS 276.37 & DQ678066 & DQ678014 & DQ677909 \\
\hline Piedraia hortae var. hortae & CBS 480.64 & GU214466 & AY016349 & - \\
\hline Pleomassaria sipariaT & CBS 279.74 & DQ678078 & DQ678027 & - \\
\hline Pleospora herbarumT & CBS 191.86 & DQ247804 & DQ247812 & DQ471090 \\
\hline Polyplosphaeria fuscaT & KT 1616 & AB524604 & AB524463 & - \\
\hline Preussia funiculataT & CBS 659.74 & GU301864 & - & - \\
\hline Prosthemium orientale & KT1669 & AB553748 & AB553641 & - \\
\hline Pseudoastrosphaeriella africana & MFLUCC 11-0176 & KT955474 & KT955454 & KT955436 \\
\hline $\begin{array}{l}\text { Pseudoastrosphaeriella } \\
\text { bambusae }\end{array}$ & MFLUCC 11-0205 & KT955475 & - & KT955437 \\
\hline Pseudoastrosphaeriella longicolla & MFLUCC 11-0171 & KT955476 & - & KT955438 \\
\hline $\begin{array}{l}\text { Pseudoastrosphaeriella } \\
\text { thailandensisT }\end{array}$ & MFLUCC 11-0144 & KT955478 & KT955457 & KT955440 \\
\hline $\begin{array}{l}\text { Pseudotetraploa } \\
\text { curviappendiculataT }\end{array}$ & HC 4930 & AB524608 & AB524467 & - \\
\hline Quadricrura septentrionalisT & HC 4984 & AB524616 & AB524475 & - \\
\hline Racodium rupestre & L346 & EU048583 & EU048575 & - \\
\hline Roccella fuciformis & Tehler 8171 & FJ638979 & - & - \\
\hline Roussoella nitidulaT & MFLUCC 11-0182 & KJ474843 & - & KJ474852 \\
\hline Roussoellopsis macrospora & MFLUCC 12-0005 & KJ474847 & - & KJ474855 \\
\hline Salsuginea ramicola & KT2597.2 & GU479801 & GU479768 & GU479862 \\
\hline Salsuginea ramicolaT & KT 2597.1 & GU479800 & GU479767 & GU479861 \\
\hline Striatiguttula phoenicis & MFLUCC 20-0093 & MT587580 & MT587572 & MT597402 \\
\hline Striatiguttula phoenicis & MFLUCC 20-0094 & MT587573 & MT587571 & MT597403 \\
\hline Striatiguttula nypaeT & MFLUCC 18-0265 & MK035992 & MK035977 & MK034432 \\
\hline Striatiguttula nypae & MFLUCC 17-2517 & MK035993 & MK035978 & MK034433 \\
\hline
\end{tabular}




\begin{tabular}{|lllll|}
\hline Striatiguttula nypae & MFLUCC 17-2518 & MK035994 & MK035979 & MK034434 \\
\hline Striatiguttula phoenicisT & MFLUCC 18-0266 & MK035995 & MK035980 & MK034435 \\
\hline Tetraplosphaeria sasicolaT & KT563 & AB524631 & AB524490 & - \\
\hline Trematosphaeria pertusaT & CBS 122371 & FJ201992 & - & - \\
\hline Triplosphaeria maximaT & KT 870 & AB524637 & AB524496 & - \\
\hline Ulospora bilgramiiT & CBS 101364 & DQ678076 & DQ678025 & DQ677921 \\
\hline Verruculina enaliaT & BCC 18401 & GU479802 & - & GU479863 \\
\hline Wicklowia aquatica & AF289-1 & GU045446 & - & - \\
\hline Wicklowia aquaticaT & F76-2 & GU045445 & GU266232 & - \\
\hline Zopfia rhizophilaT & CBS 207.26 & DQ384104 & - & - \\
\hline
\end{tabular}

Abbreviations: ATCC: American Type Culture Collection, Virginia, USA; BBH: Biotec Bangkok Herbarium, Thai-land; BCC: BIOTEC Culture Collection, Bangkok, Thailand; CBS: Central bureauvoor Schimmel cultures, Utrecht, The Netherlands; CPC: Collection of Pedro Crous house dat CBS; DAOM: Plant Research Institute, Department of Agriculture (Mycology), Ottawa, Canada; GZCC: Guizhou Culture Collection; IFRDCC: Culture Collection, International Fungal Research and Development Centre, Chinese Academy of Forestry, Kunming, China; JCM: the Japan Collection of Microorganisms, Japan; MAFF: Ministry of Agriculture, Forestry and Fisheries, Japan; MFLU: Mae Fah Luang University Herbarium Collection; MFLUCC: Mae Fah Luang University Culture Collection, Chiang Rai, Thailand. ANM: A.N. Miller; GKM: G.K. Mugambi; JK: J. Kohlmeyer; KT: K. Tanaka; SMH: S.M. Huhndorf

Table 2 List of Rhytidhysteron (Hysteriales) taxa used in this study along with their GenBank Accession numbers. The new sequence in bold. $T$ represents Type species of the genus. 


\begin{tabular}{|c|c|c|c|c|c|}
\hline \multirow[b]{2}{*}{ Taxa } & \multirow[b]{2}{*}{ Strain/Culture } & \multicolumn{4}{|c|}{ GenBank Accession numbers } \\
\hline & & LSU & SSU & tef1 & ITS \\
\hline Gloniopsis praelonga & CBS 112415 & FJ161173 & FJ161134 & FJ161090 & - \\
\hline Rhytidhysteron bruguierae $T$ & MFLUCC 18-0398 & MN017833 & MN017901 & MN077056 & - \\
\hline Rhytidhysteron chromolaenae & MFLUCC 17-1516 & MN632456 & MN632467 & MN635663 & MN632461 \\
\hline Rhytidhysteron hysterinum & EB 0351 & GU397350 & - & GU397340 & - \\
\hline Rhytidhysteron kirshnacephalus & MFLUCC 18-1111 & MT612351 & - & MT674994 & MT712758 \\
\hline Rhytidhysteron magnoliae $T$ & MFLUCC 18-0719 & MN989384 & MN989382 & MN997309 & MN989383 \\
\hline Rhytidhysteron mangrovei $T$ & MFLUCC 18-1113 & MK357777 & - & MK450030 & NR_165548 \\
\hline Rhytidhysteron neorufulum $T$ & MFLUCC 13-0216 & KU377566 & KU377571 & KU510400 & KU377561 \\
\hline Rhytidhysteron neorufulum & GKM 361A & GQ221893 & GU296192 & GU349031 & - \\
\hline Rhytidhysteron neorufulum & HUEFS 192194 & KF914915 & - & - & - \\
\hline Rhytidhysteron neorufulum & CBS 306.38 & FJ469672 & AF164375 & GU349031 & - \\
\hline Rhytidhysteron neorufulum & MFLUCC 12-0567 & KJ526126 & KJ546129 & - & KJ546124 \\
\hline Rhytidhysteron neorufulum & MFLUCC 12-0569 & KJ526128 & KJ546131 & - & KJ546126 \\
\hline Rhytidhysteron neorufulum & EB 0381 & GU397351 & GU397366 & - & - \\
\hline Rhytidhysteron opuntiae & GKM 1190 & GQ221892 & - & GU397341 & - \\
\hline Rhytidhysteron rufulum $T$ & MFLUCC 14-0577 & KU377565 & KU377570 & KU510399 & KU377560 \\
\hline Rhytidhysteron rufulum & EB 0384 & GU397354 & GU397368 & - & - \\
\hline Rhytidhysteron rufulum & EB 0382 & GU397352 & - & - & - \\
\hline Rhytidhysteron rufulum & EB 0383 & GU397353 & GU397367 & - & - \\
\hline Rhytidhysteron rufulum & MFLUCC 12-0013 & KJ418111 & KJ418113 & - & KJ418112 \\
\hline Rhytidhysteron thailandicum $T$ & MFLUCC 14-0503 & KU377564 & KU377569 & KU497490 & KU377559 \\
\hline Rhytidhysteron thailandicum & MFLUCC 12-0530 & KJ526125 & KJ546128 & - & KJ546123 \\
\hline Rhytidhysteron tectonae $T$ & MFLUCC 13-0710 & KU764698 & KU712457 & KU872760 & KU144936 \\
\hline
\end{tabular}

Abbreviations: GKM: G.K. Mugambi, EB: E.W.A. Boehm, MFLUCC: Mae Fah Luang University Culture Collection, CBS: Central bureau voor Schimmelcultures

Table 3 Morphological comparison between species of Striatiguttula 


\begin{tabular}{|c|c|c|c|c|c|c|c|c|}
\hline \multirow[t]{2}{*}{ Taxa } & \multicolumn{3}{|c|}{ Ascomata } & \multirow{2}{*}{$\begin{array}{l}\text { Hamathecium, } \\
\text { Pseudopar- } \\
\text { aphyses } \\
(\mu \mathrm{m})\end{array}$} & \multirow{2}{*}{$\begin{array}{l}\text { Asci } \\
(\mu \mathrm{m})\end{array}$} & \multicolumn{3}{|c|}{ Ascospores } \\
\hline & $\begin{array}{l}\text { Ascomata } \\
\text { morphology }\end{array}$ & $\begin{array}{l}\text { (high } x \\
\text { diam. } \\
\mu \mathrm{m} \text { ) }\end{array}$ & $\begin{array}{l}\text { Peridium } \\
(\mu \mathrm{m})\end{array}$ & & & $\begin{array}{l}\text { Ascospores } \\
\text { morphology }\end{array}$ & $\begin{array}{l}\text { Ascospores } \\
\text { size }(\mu \mathrm{m})\end{array}$ & References \\
\hline $\begin{array}{l}\text { Striatiguttula } \\
\text { phoenicis } \\
\text { (MFLU 19- } \\
2847 \text { ) }\end{array}$ & $\begin{array}{l}\text { Immersed, } \\
\text { erumpent, } \\
\text { ampulliform, } \\
\text { subglobose } \\
\text { or } \\
\text { conical }\end{array}$ & $\begin{array}{l}250-380 \\
\times 195- \\
310\end{array}$ & $30-90$ & $\begin{array}{l}\text { Purple, 1.75- } \\
2.5\end{array}$ & $\begin{array}{l}64- \\
128 \\
\times 9- \\
13.8\end{array}$ & $\begin{array}{l}\text { oval, } \\
\text { ellipsoidal } \\
\text { to fusiform } \\
0-3 \text {-septate }\end{array}$ & $\begin{array}{l}13-32 \times \\
6.4-8\end{array}$ & This study \\
\hline $\begin{array}{l}\text { Striatiguttula } \\
\text { nypae }\end{array}$ & $\begin{array}{l}\text { Immersed } \\
\text { and } \\
\text { erumpent to } \\
\text { superficial, } \\
\text { subglobose } \\
\text { or conical, } \\
\text { uni-loculate } \\
\text { or bi- } \\
\text { loculate, }\end{array}$ & $\begin{array}{l}240-380 \\
\times 195- \\
385\end{array}$ & $9-16$ & Hyaline, 1-2 & $\begin{array}{l}64- \\
145 \\
\times 8- \\
17\end{array}$ & $\begin{array}{l}\text { Fusiform, } \\
\text { 1-3-septate }\end{array}$ & $\begin{array}{l}18-26 \times \\
4-6\end{array}$ & $\begin{array}{l}\text { Zhang et } \\
\text { al. } 2019\end{array}$ \\
\hline $\begin{array}{l}\text { Striatiguttula } \\
\text { phoenicis }\end{array}$ & $\begin{array}{l}\text { Immersed, } \\
\text { erumpent, } \\
\text { ampulliform, } \\
\text { subglobose, } \\
\text { uni } \\
\text { loculate }\end{array}$ & $\begin{array}{l}195-580 \\
\times 135- \\
390\end{array}$ & $10-24$ & Hyaline, 1-2 & $\begin{array}{l}89- \\
141 \\
\times \\
12- \\
18\end{array}$ & $\begin{array}{l}\text { Fusiform to } \\
\text { ellipsoidal, } \\
1-3- \\
\text { septate, } \\
\text { nearly } \\
\text { concolorous }\end{array}$ & $\begin{array}{l}20-29 x \\
6-10\end{array}$ & $\begin{array}{l}\text { Zhang et } \\
\text { al. } 2019\end{array}$ \\
\hline
\end{tabular}




\begin{tabular}{|c|c|c|c|c|c|c|}
\hline \multirow{2}{*}{$\begin{array}{l}\text { Rhytidhysteron } \\
\text { Taxa }\end{array}$} & \multirow[b]{2}{*}{$\begin{array}{l}\text { Ascoma } \\
\text { margins }\end{array}$} & \multirow[b]{2}{*}{$\begin{array}{l}\text { (high × diam. } \\
\mu \mathrm{m})\end{array}$} & \multirow[b]{2}{*}{ Pruina } & \multirow{2}{*}{$\begin{array}{l}\text { Asci (number } \\
\text { of spores) }\end{array}$} & \multirow[t]{2}{*}{ Ascospores $(\mu \mathrm{m})$} & \multirow[t]{2}{*}{ References } \\
\hline & & & & & & \\
\hline $\begin{array}{l}\text { Rhytidhysteron } \\
\text { brasiliense }\end{array}$ & $\begin{array}{l}\text { Rough-without } \\
\text { striations }\end{array}$ & $\begin{array}{l}1087-1715 \times \\
340-447\end{array}$ & & 8 & $\begin{array}{l}\text { 1-3-septate, } 40-45 \\
\times 12-20\end{array}$ & $\begin{array}{l}\text { Thambugala et al. } \\
2016\end{array}$ \\
\hline Rh. bruguierae & Rough-Striate & $\begin{array}{l}400-950 \times \\
548-570\end{array}$ & $\begin{array}{l}\text { Dark } \\
\text { brown }\end{array}$ & $6-8$ & $\begin{array}{l}\text { 1-3-septate, } 14-26 \\
\times 6.2-9\end{array}$ & $\begin{array}{l}\text { Dayarathne et al. } \\
2020\end{array}$ \\
\hline $\begin{array}{l}\text { Rh. } \\
\text { columbiense }\end{array}$ & Striate & $\begin{array}{l}1500-3000 \times \\
1200-1800\end{array}$ & & $6-8$ & $38-52 \times 13-18$ & $\begin{array}{l}\text { Soto-Medina and } \\
\text { Lucking } 2018\end{array}$ \\
\hline Rh. hysterinum & Smooth-Striate & $\begin{array}{l}1000-3000 \times \\
500\end{array}$ & & $4-8$ & $\begin{array}{l}\text { 1-septate, } 20-32 \times \\
12-15\end{array}$ & $\begin{array}{l}\text { Samuels and } \\
\text { Müller } 1980\end{array}$ \\
\hline Rh. magnoliae & $\begin{array}{l}\text { Distinct } \\
\text { striation }\end{array}$ & $\begin{array}{l}1200-2300 \times \\
540- \\
600\end{array}$ & $\begin{array}{l}\text { Dark } \\
\text { brown }\end{array}$ & 8 & $\begin{array}{l}\text { 1-3-septate, } \\
(25-32 \times 8-12) \\
\mu \mathrm{m}\end{array}$ & $\begin{array}{l}\text { De Silva et al. } \\
2020\end{array}$ \\
\hline Rh. mangrovei & Rough-Striate & $\begin{array}{l}930-1980 \times \\
785-910\end{array}$ & $\begin{array}{l}\text { Brick- } \\
\text { red }\end{array}$ & $2-(-6)-8$ & $\begin{array}{l}\text { 1-3-septate, } 21-28 \\
\times 7.5-8.5\end{array}$ & Kumar et al. 2019 \\
\hline Rh. neorufulum & $\begin{array}{l}\text { Rough-without } \\
\text { striations }\end{array}$ & $\begin{array}{l}835-1800 \times \\
600-1320\end{array}$ & & 8 & $\begin{array}{l}\text { 1-3-septate, } 27-34 \\
\times 6.5-12.5\end{array}$ & $\begin{array}{l}\text { Thambugala et al. } \\
2016\end{array}$ \\
\hline Rh. rufulum & Striate & $\begin{array}{l}900-2350 \times \\
1134-1450\end{array}$ & & 8 & $\begin{array}{l}1-3 \text {-septate, } 21-36 \\
\times 9-13\end{array}$ & $\begin{array}{l}\text { Thambugala et al. } \\
2016\end{array}$ \\
\hline Rh. tectonae & Striate & $\begin{array}{l}1225-3365 \times \\
370-835\end{array}$ & & 8 & $\begin{array}{l}\text { 1-septate, } 19-31 \times \\
8-13\end{array}$ & Doilom et al. 2017 \\
\hline $\begin{array}{l}\text { Rh. } \\
\text { kirshnacephalus }\end{array}$ & $\begin{array}{l}\text { Smooth- } \\
\text { without } \\
\text { striations }\end{array}$ & $\begin{array}{l}1200-1800 \times \\
480-750\end{array}$ & Black & $4-6$ & $\begin{array}{l}\text { 1-3-septate, } 16.5- \\
22 \times 6.0-7.5 \mu \mathrm{m}\end{array}$ & This study \\
\hline $\begin{array}{l}\text { Rh. } \\
\text { thailandicum }\end{array}$ & $\begin{array}{l}\text { Rough-without } \\
\text { striations }\end{array}$ & $\begin{array}{l}700-1200 \times \\
530-750\end{array}$ & & $(3-) 6-8$ & $\begin{array}{l}\text { 3-septate, } 20-31 \times \\
7.5-12\end{array}$ & $\begin{array}{l}\text { Thambugala et al. } \\
2016\end{array}$ \\
\hline
\end{tabular}

Table 5 List of Lasiodiplodia (Botryosphaeriales) taxa used in this study along with their GenBank Accession numbers. The new sequence in bold 


\begin{tabular}{|c|c|c|c|}
\hline \multirow[t]{2}{*}{ Taxa } & \multirow[t]{2}{*}{ Strain/Culture } & \multicolumn{2}{|c|}{ GenBank Accession numbers } \\
\hline & & ITS & TEF \\
\hline Lasiodiplodia avicenniae & CMW 41467 & KP860835 & KP860680 \\
\hline L. avicenniarum & MFLUCC 17-2591 & NR_163344 & MK340867 \\
\hline L. brasiliensis & CMM4015 & JX464063 & JX464049 \\
\hline L. bruguierae & CMW42480 & KP860832 & KP860677 \\
\hline L. caatinguensis & IBL366 & KT154760 & KT008006 \\
\hline L. chinensis & CGMCC 3.18061 & KX499889 & KX499927 \\
\hline L. citricola & IRAN1522C & GU945354 & GU945340 \\
\hline L. citricola & MFLUCC 18-1115 & MK106111 & - \\
\hline L. crassispora & WAC12533 & DQ103550 & DQ103557 \\
\hline L. euphorbicola & СММ3609 & KF234543 & KF226689 \\
\hline L. exigua & BL104 & KJ638317 & KJ638336 \\
\hline L. gilanensis & IRAN1523C & GU945351 & GU945342 \\
\hline L. gonubiensis & CMW14077 & AY639595 & DQ103566 \\
\hline L. gravistriata & CMM4564 & KT250949 & KT250950 \\
\hline L. hormozganensis & IRAN1500C & NR_147329 & GU945343 \\
\hline L. hyalina & CGMCC 3.17975 & NR_152982 & KX499917 \\
\hline L. iraniensis & IRAN921C & GU945346 & GU945334 \\
\hline L. laeliocattleyae & CBS 167.28 & NR_147364 & KU507454 \\
\hline L. lignicola & MFLUCC 11-0435 & NR_111795 & JX646862 \\
\hline L. macrospora & СММ3833 & NR_147349 & KF226718 \\
\hline L. mahajangana & CMW 27801 & FJ900595 & FJ900641 \\
\hline L. margaritacea & CBS 122519 & NR_136998 & EU144065 \\
\hline L. mediterranea & BL1 & KJ638312 & KJ638331 \\
\hline L. missouriana & UCD2193MO & HQ288226 & HQ28826 \\
\hline L. parva & CBS 456.78 & NR_111265 & EF622063 \\
\hline L. plurivora & STEU 5803 & EF445362 & EF445395 \\
\hline L. pontae & IBL12 & KT151794 & KT15179 \\
\hline L. pseudotheobromae & CBS116459 & NR_111264 & EF622057 \\
\hline L. pyriformis & CBS 121770 & NR_136993 & EU101352 \\
\hline L. rubropurpurea & WAC12535 & DQ103553 & DQ103571 \\
\hline L. sterculiae & CBS 342.78 & NR_147365 & KX464634 \\
\hline L. subglobosa & СMM3872 & NR_147350 & KF226721 \\
\hline L. thailandica & CPC:22755 & KM006433 & KM006464 \\
\hline L. theobroame & CBS 164.96 & NR_111174 & AY640258 \\
\hline
\end{tabular}

Page 27/45 


\begin{tabular}{|llll|}
\hline L. venezuelensis & WAC 12539 & NR_136975 & DQ103568 \\
\hline L. viticola & UCD 2553AR & HQ288227 & HQ288269 \\
\hline L. vitis & CBS 124060 & KX464148 & KX464642 \\
\hline L. cinnamomi & CFCC 51997 & MG866028 & MH236799 \\
\hline L. chonburiensis & MFLUCC 16-0376 & MH275066 & MH412773 \\
\hline L. pandanicola & MFLUCC 16-0265 & MH275068 & MH412774 \\
\hline L. swieteniae & MFLUCC 18-0244 & MK347789 & MK340870 \\
\hline Barriopsis iraniana & IRAN1448C & NR_137030 & FJ919652 \\
\hline B. tectonae & CMW40687 & NR_137616 & KJ556517 \\
\hline
\end{tabular}

Abbreviations: CMW: FABI fungal culture collection, IBL: Botanical Institute, Lisbon Faculty of Sciences, Lisbon, Portugal, CGMCC: China General Microbiological Culture Collection Center, IRAN: Iranian Fungal Culture Collection, WAC: Department of Agriculture and Food Western Australia Plant Pathology Collection, BL: B.T. Linaldeddu, UCD: Phaff Yeast Culture Collection, Department of Food Science and Technology, University of California, Davis, CPC: Collection of Pedro Crous housed at CBS, CFCC: China Forestry Culture Collection Center, CBS: Centraal bureau voor Schimmel cultures, MFLUCC: Mae Fah Luang University Culture Collection, STEU: University of Stellenbosch fungal culture collection

Table 6 List of fungi occurring on the aerial parts of mangrove trees with their different mode of nutrition. 


\begin{tabular}{|c|c|c|c|}
\hline Name & Host & Locality & Reference \\
\hline Acidiella uranophila & $\begin{array}{l}\text { Leaves of Acanthus ilicifolius var. } \\
\text { xiamenensis }\end{array}$ & Taiwan & Wei-Chiung Chi et al. 2019 \\
\hline $\begin{array}{l}\text { Acremonium } \\
\text { alternatum }\end{array}$ & Roots of Rhizophora mucronata & India & Ananda and Sridhar 2002 \\
\hline $\begin{array}{l}\text { Akanthomyces } \\
\text { muscarius }\end{array}$ & Leaves of Nypa fruticans & Thailand & Kumar et al. 2018 \\
\hline Alternaria alternata & $\begin{array}{l}\text { Phylloplane of Avicennia marina, } \\
\text { Leaves of Acanthus ilicifolius, Acanthus } \\
\text { ihcifolius, Arthrocnemum indicum, } \\
\text { Lummtzera racemosa, Rhizophora } \\
\text { apiculata }\end{array}$ & $\begin{array}{l}\text { India, } \\
\text { Taiwan }\end{array}$ & $\begin{array}{l}\text { Wei-Chiung Chi et al. 2019, Kumaresan } \\
\text { and Suryanarayanan 2001, Kumaresan } \\
\text { and Suryanarayan 2002, } \\
\text { Suryanarayanan and Kumaresan 2000, } \\
\text { Suryanaryanan et al 1998, Nayak and } \\
\text { Anandhu } 2017\end{array}$ \\
\hline Ampullifera sp. & - & India & Suryanarayanan and Kumaresna 2000 \\
\hline $\begin{array}{l}\text { Anthostomella } \\
\text { eructans }\end{array}$ & Fronds of Nypa fruticans & Brunei & Hyde and Sarma 2006 \\
\hline Anthostomella sp. & Fronds of Nypa fruticans & Brunei & Hyde and Sarma 2006 \\
\hline $\begin{array}{l}\text { Apiognomonia } \\
\text { catappae }\end{array}$ & Leaves of Terminalia catappa & Indonesia & Koorders 1907 \\
\hline $\begin{array}{l}\text { Apiognomonia } \\
\text { terminaliae }\end{array}$ & Leaves of Terminalia catappa & Japan & Katumoto and Harada 1979 \\
\hline $\begin{array}{l}\text { Ascochytella } \\
\text { rhizophoropsis }\end{array}$ & Living leaves of Rhizophora sp. & $\begin{array}{l}\text { Dominican } \\
\text { Republic }\end{array}$ & Gonzalez Fragoso and Ciferri 1926 \\
\hline $\begin{array}{l}\text { Ascochytella } \\
\text { thespesiae }\end{array}$ & Leaves of Thespesia populnea & $\begin{array}{l}\text { Dominican } \\
\text { Republic }\end{array}$ & Gonzalez Fragoso and \\
\hline Ascotricha chartarum & $\begin{array}{l}\text { Leaves of Acrostichum aureum, } \\
\text { Rhizophora mucronata }\end{array}$ & India & $\begin{array}{l}\text { Ananda and Sridhar 2002, Maria and } \\
\text { Sridhar } 2003\end{array}$ \\
\hline Aspergillus awamori & Phylloplane of Avicennia marina & India & Nayak and Anandhu 2017 \\
\hline Aspergillus candidus & Leaves of Rhizophora mucronata & Pakistan & Tariq et al. 2006 \\
\hline Aspergillus flavus & $\begin{array}{l}\text { Leaves of Acanthus ilicifolius, Avicennia } \\
\text { germinans, Avicennia marina, } \\
\text { Rhizophora apiculata, Rhizophora } \\
\text { mucronata }\end{array}$ & $\begin{array}{l}\text { Texas } \\
\text { (USA), India, } \\
\text { Mexico, } \\
\text { Malaysia }\end{array}$ & $\begin{array}{l}\text { Chowdhery and Rai 1980, Koehn and } \\
\text { Garrison 1981, Kuthubutheen 1984, Rai } \\
\text { et al. 1969, Nayak and Anandhu } 2017\end{array}$ \\
\hline Aspergillus fumigatus & Living leaves of Avicennia germinans & $\begin{array}{l}\text { India, } \\
\text { Japan, } \\
\text { Hawaii, } \\
\text { Malaysia, } \\
\text { Pakistan }\end{array}$ & $\begin{array}{l}\text { Chowdhery and Rai 1980, Ito and } \\
\text { Nakagiri 1997, Kuthubutheen 1984, Lee } \\
\text { and Baker 1972, Rai et al. 1969, Tariq et } \\
\text { al. 2006, Thorati et al. } 2016\end{array}$ \\
\hline Aspergillus glaucus & Leaves of Rhizophora mucronata & India & $\begin{array}{l}\text { Kumaresan and Suryanarayanan } 2001, \\
\text { Kumaresan and Suryanarayan } 2002, \\
\text { Suryanarayanan and Kumaresan 2000, } \\
\text { Suryanaryanan et al } 1998\end{array}$ \\
\hline Aspergillus nidulans & Leaves of Avicennia marina & India & Nayak and Anandhu 2017 \\
\hline Aspergillus niger & $\begin{array}{l}\text { Leaves of Avicennia marina, Ceriops } \\
\text { decandra, Excoecana agallocha, } \\
\text { Rhizophora mucronata }\end{array}$ & $\begin{array}{l}\text { India, } \\
\text { Pakistan, } \\
\text { Texas } \\
\text { (USA), India, } \\
\text { Hawaii, } \\
\text { Japan, } \\
\text { Mexico, } \\
\text { Singapore, } \\
\text { Malaysia }\end{array}$ & $\begin{array}{l}\text { Kumaresan and Suryanarayanan 2001, } \\
\text { Kumaresan and Suryanarayan } 2002, \\
\text { Suryanarayanan and Kumaresan 2000, } \\
\text { Suryanaryanan et al. 1998, Tariq et al. } \\
\text { 2006, Nayak and Anandhu 2017, } \\
\text { Chowdhery and Rai 1980, Ito and } \\
\text { Nakagiri 1997, Koehn and Garrison } \\
\text { 1981, Kuthubutheen 1984, Newell, } \\
\text { Steven Y. 1976. Newell 1973 }\end{array}$ \\
\hline Aspergillus ochraceus & Leaves of Avicennia marina & India & Nayak and Anandhu 2017 \\
\hline
\end{tabular}




\begin{tabular}{|c|c|c|c|}
\hline Aspergillus parasiticus & Leaves of Rhizophora mucronata & Pakistan & Tariq et al. 2006 \\
\hline Aspergillus sp. & Leaves of Avicennia marina & India & Nayak and Anandhu 2017 \\
\hline Aspergillus sulphureus & Leaves of Rhizophora mucronata & Pakistan & Tariq et al. 2006 \\
\hline Aspergillus terreus & Leaves and Stems of Avicennia marina & $\begin{array}{l}\text { Texas } \\
\text { (USA), India, } \\
\text { Mexico, } \\
\text { Japan, } \\
\text { Florida } \\
\text { (USA), } \\
\text { Malaysia }\end{array}$ & $\begin{array}{l}\text { Chowdhery and Rai 1980, , Ito and } \\
\text { Nakagiri 1997, Koehn and Garrison } \\
\text { 1981, Kuthubutheen 1984, Nayak and } \\
\text { Anandhu } 2017 \text { Newell } 1976\end{array}$ \\
\hline Aspergillus versicolar & Leaves of Avicennia marina & India & Nayak and Anandhu 2017 \\
\hline Aspergillus wentii & Leaves of Rhizophora mucronata & Pakistan & Tariq et al. 2006 \\
\hline $\begin{array}{l}\text { Asteridiella } \\
\text { lagunculariae }\end{array}$ & Living leaves of Laguricularia racemosa & Porto Rico & Earle 1901 \\
\hline Asteridiella nigra & Living leaves of Laguricularia racemosa & Porto Rico & Stevens 1916 \\
\hline Asteridiella pavoniae & On Pavonia spicata & $\begin{array}{l}\text { Dominican } \\
\text { Republic }\end{array}$ & Ciferri 1954 \\
\hline Asteridiella sepulta & Leaves of Avicennia sp. & & Patouillard 1916 \\
\hline Asterina ciferriana & Living leaves of Caesalpinia crista & $\begin{array}{l}\text { Dominican } \\
\text { Republic }\end{array}$ & Petrak and Cifferi 1932 \\
\hline Asterina derridis & Leaves of Derris trifoliata & $\begin{array}{l}\text { Kenya and } \\
\text { Madagascar }\end{array}$ & Hennings 1908 \\
\hline $\begin{array}{l}\text { Aureobasidium } \\
\text { pullulans }\end{array}$ & $\begin{array}{l}\text { Living leaves and seedlings of } \\
\text { Avicennia germinans, Avicennia marina, } \\
\text { Rhziophora mangle }\end{array}$ & $\begin{array}{l}\text { Mexico, } \\
\text { Venezuela, } \\
\text { Malaysia, } \\
\text { Florida } \\
\text { (USA), India, } \\
\text { Japan, } \\
\text { Hawaii, } \\
\text { Taiwan }\end{array}$ & $\begin{array}{l}\text {, Kohlmeyer and Kohlmeyer 1979, } \\
\text { Kuthubutheen 1981, Kuthubutheen } \\
\text { 1984, Meyers et al. 1965, Newell 1976, } \\
\text { Newell 1973, Newell and Fell 1980, Wei- } \\
\text { Chiung Chi et al. } 2019\end{array}$ \\
\hline Barriopsis fusca & On Hibiscus tiliaceus & - & Stevens 1926 \\
\hline Bipolaris victoriae & Leaves of Avicennia marina & India & Nayak and Anandhu 2017 \\
\hline $\begin{array}{l}\text { Botryodiplodia } \\
\text { thespesiae }\end{array}$ & Dead branch of Thespesia populnea & $\begin{array}{l}\text { Dominican } \\
\text { Republic }\end{array}$ & Petrak and Cifferi 1930 \\
\hline $\begin{array}{l}\text { Botryosphaeria } \\
\text { dothidea }\end{array}$ & $\begin{array}{l}\text { Leaves of Acanthus ilicifolius var. } \\
\text { xiamenensis }\end{array}$ & Taiwan & Wei-Chiung Chi et al. 2019 \\
\hline $\begin{array}{l}\text { Botryosphaeria } \\
\text { quercuum }\end{array}$ & Leaves of Laguricularia racemosa & Brazil & Rehm 1901 \\
\hline Botrytis argillacea & Bark of Avicennia eucalyptifolia & Austrailia & McAlpine 1897 \\
\hline $\begin{array}{l}\text { Camarosporium } \\
\text { palliatum }\end{array}$ & $\begin{array}{l}\text { Leaves of Arthrocnemum indicum, } \\
\text { Suaeda maritima, Aerial leaves and } \\
\text { seedlings of Thalassium testinudum, } \\
\text { Ceriopsis tagal, Rhizophora magle }\end{array}$ & India & $\begin{array}{l}\text { Kumaresan and Suryanarayanan 2001, } \\
\text { Kumaresan and Suryanarayan 2002, } \\
\text { Suryanarayanan and Kumaresan 2000, } \\
\text { Suryanaryanan et al. 1998, Borse et al. } \\
\text { 1988, Kohlmeyer and Kohlmeyer } 1979, \\
\text { Suryanarayanan and Kumaresna } 2000\end{array}$ \\
\hline Capnobotrys hibisci & Leaves of Hibiscus tiliaceus & Cuba & Mercado 1984 \\
\hline Cercospora geraisensis & Leaves of Terminalia catappa & Brazil & Chupp 1954 \\
\hline $\begin{array}{l}\text { Cercospora } \\
\text { rhizoyhorae }\end{array}$ & Leaves of Rhizophora mangle & Florida, USA & Creager 1962 \\
\hline
\end{tabular}


Cercosporella

thespesiae

Chaetomium

globosum
Endophyte of Arthrocnemum indicum, India On Thespesia populnea

Leaves of Avicennia marina, Rhizophora India apiculata, Rhizophora mucronata,

Thespeisa populnea
Poonyth et al. 2000

Kumaresan and Suryanarayanan 2001,

Kumaresan and Suryanarayan 2002,

Suryanarayanan and Kumaresan 2000,

Suryanaryanan et al 1998,

Kuthubutheen 1981, Poon and Hyde

1998, Suryanarayanan et al. 1998,

Guerrero et al. 2018

\begin{tabular}{|c|c|c|c|}
\hline $\begin{array}{l}\text { Cladosporium } \\
\text { cladosporioides }\end{array}$ & $\begin{array}{l}\text { Leaves of Avicennia marina, Avicennia } \\
\text { officinalis, Ceriops decandra, } \\
\text { Lumnitzera racemosa, Rhizophora } \\
\text { apiculata, Rhizophora mucronata }\end{array}$ & India & $\begin{array}{l}\text { Kumaresan and Suryanarayanan } 2001 \\
\text { Kumaresan and Suryanarayan } 2002 \text {, } \\
\text { Suryanarayanan and Kumaresan } 2000 \\
\text { Suryanaryanan et al 1998, Tariq et al. } \\
2006\end{array}$ \\
\hline
\end{tabular}

dominicanum xiamenensis

Cladosporium Endophyte, living leaves of Rhizophora

marinum

apiculata, Rhizophora mucronata,

Phragmities australis, Avicennia marina

Cladosporium
oxysporum

Roots of Avicennia officinalis,

Rhizophora mucronata

India, Hong Poonyth et al. 2000.

Kong

India

Ananda and Sridhar 2002

Roots of Rhizophora mucronata

India

Ananda and Sridhar 2002

psoraleae

Colletotrichum

boninense

Leaves of Acanthus ilicifolius var. xiamenensis

Taiwan

Wei-Chiung Chi et al. 2019

Leaves of Avicennia schaueriana,
Colletotrichum

gloeosporioides

Lumnitzera racemosa, Rhizophora

Brazil, India

mangle, Bruguiera cylindrica

Kumaresan and Suryanarayanan 2001, Kumaresan and Suryanarayan 2002, Suryanarayanan and Kumaresan 2000, Suryanaryanan et al 1998, Costa et al. 2012

Brazil Costa et al. 2012

Leaves of Avicennia schaueriana,

Lumnitzera racemosa, Rhizophora mangle

gloeosporioides

Leaves of Acanthus ilicifolius var. xiamenensis

hippeastri

Leaves of Avicennia marina

Taiwan

Wei-Chiung Chi et al. 2019

Colletotrichum sp.

Leaves of Acanthus ilicifolius var.

$\begin{aligned} \text { Corynespora cassiicola } & \begin{array}{l}\text { Leaves of } A c \\ \text { xiamenensis }\end{array}\end{aligned}$

Coryneum calophylli On Calophyllum inophyllum

Crepidotus

krieglsteineri

Dead wood of Rhizophora mangle

Crustoderma

vulcanense

Curvularia

australiensis

Curvularia lunata

Leaves of Rhizophora mucronata

Curvularia pallescens

Leaves of Avicennia marina, Lumnitzera
Dead Plant

Hawaii

Gilbertson and Adaskaveg 1993

Leaves of Avicennia officinalis, $A$.

marina, Lumnitzera racemosa,

Rhizophora apiculata

India

India

Taiwan

Nayak and Anandhu 2017

Philippines

Sydow and Sydow 1914

Florida, USA Singer 1988

Pakistan Tariq et al. 2006

India

Kumaresan and Suryanarayanan 2001, Kumaresan and Suryanarayan 2002, Suryanarayanan and Kumaresan 2000, Suryanaryanan et al 1998, Nayak and Anandhu 2017, Hamzah et al. 2018

racemosa
Kumaresan and Suryanarayanan 2001, Kumaresan and Suryanarayan 2002,

Suryanarayanan and Kumaresan 2000, Suryanaryanan et al. 1998 


\begin{tabular}{|c|c|c|c|}
\hline Cyphellophora sp. & Stem canker of Avicennia marina & South Africa & Osorio et al. 2017 \\
\hline $\begin{array}{l}\text { Cytospora } \\
\text { lumnitzericola }\end{array}$ & leaf spot of Lumnitzera racemosa & Thailand & Norphanphoun et al. 2018 \\
\hline Cytospora pinastri & Roots of Sonneratia caseolans & India & Ananda and Sridhar 2002 \\
\hline $\begin{array}{l}\text { Dacrymyces } \\
\text { intermedius }\end{array}$ & Dead twig of Hibiscus tiliaceus & Tahiti & Olive 1958 \\
\hline Dactylaria purpurella & Roots of Acanthus ihcifolius & India & Ananda and Sridhar 2002 \\
\hline Daldinia eschscholtzii & $\begin{array}{l}\text { Leaves of Acanthus ilicifolius var. } \\
\text { xiamenensis }\end{array}$ & Taiwan & Wei-Chiung Chi et al. 2019 \\
\hline Diaporthe endophytica & $\begin{array}{l}\text { Leaves of Acanthus ilicifolius var. } \\
\text { xiamenensis }\end{array}$ & Taiwan & Wei-Chiung Chi et al. 2019 \\
\hline $\begin{array}{l}\text { Diaporthe } \\
\text { hongkongensis }\end{array}$ & Leaves of Nypa fruticans & India & Rajamani et al. 2018 \\
\hline Diaporthe perseae & $\begin{array}{l}\text { Leaves of Acanthus ilicifolius var. } \\
\text { xiamenensis }\end{array}$ & Taiwan & Wei-Chiung Chi et al. 2019 \\
\hline $\begin{array}{l}\text { Dictyochaeta } \\
\text { tumidoseta }\end{array}$ & Dead raches of Oncosperma tigillarium & Malaysia & Kuthubutheen and Nawawi 1991 \\
\hline Diplodfa Catappae & Nuts of Terminalia catappa & India & Cooke 1876 \\
\hline Diplodia inocarpi & $\begin{array}{l}\text { Cortex of rotting fuite (Inocarpus } \\
\text { fagifer) }\end{array}$ & Singapore & Saccardo 1918 \\
\hline Dothioraceae sp. & $\begin{array}{l}\text { Leaves of Acanthus ilicifolius var. } \\
\text { xiamenensis }\end{array}$ & Taiwan & Wei-Chiung Chi et al. 2019 \\
\hline Dothiorella calophylli & $\begin{array}{l}\text { Living leaves and endophyte of } \\
\text { Aegicera conriculatum, Rhizophora } \\
\text { mucronata, On Calophyllum inophyllum }\end{array}$ & India & Poonyth et al. 2000 \\
\hline Dothiorella indica & Pods of Pongamia pinnata & India & Soni et al. 1983 \\
\hline Drechslera sp. & Leaves of Avicennia marina & India & Nayak and Anandhu 2017 \\
\hline Dwibeeja sundara & Bark of Calophyllum & Singapore & Subramanian 1992 \\
\hline Ellisembia crassispora & Fronds of Nypa fruticans & Brunei & Hyde and Sarma 2006 \\
\hline Elsinoe terminaliae & On Terminalia catappa & Brazil & Bitancourt 1937 \\
\hline Endothiella coccolobae & & Bermuda & Roane 1986 \\
\hline $\begin{array}{l}\text { Eudimeriolum } \\
\text { avicenniae }\end{array}$ & Leaves of Avicennia sp. & Tanzania & Hansford 1946 \\
\hline Eutypella pongamiae & Dry twigs of Pongamia pinnata & India & Agarwal and Gypli \\
\hline Eutypella sp. & Branch canker of Avicennia marina & South Africa & Osorio et al. 2017 \\
\hline Exserohilum rostratum & $\begin{array}{l}\text { Living leaves of Avicennia marina, } \\
\text { Lumnitzera racemosa }\end{array}$ & $\begin{array}{l}\text { Malaysia, } \\
\text { Singapore, } \\
\text { Florida } \\
\text { (USA), India, } \\
\text { USA }\end{array}$ & $\begin{array}{l}\text { Kohlmeyer and Kohlmeyer 1979, } \\
\text { Kuthubutheen 1981, Kuthubutheen } \\
\text { 1984, Leong et al. 1988, Kumaresan } \\
\text { and Suryanarayanan 2001, Kumaresan } \\
\text { and Suryanarayan 2002, } \\
\text { Suryanarayanan and Kumaresan 2000, } \\
\text { Suryanaryanan et al. } 1998\end{array}$ \\
\hline Fasciatispora petrakii & Rachid of Nypa fruticans & Malaysia & Hyde and Alias 1999 \\
\hline Fomes avicenniae & Trunk of Avicennia marina & Somalia & Poonyth et al. 2000 \\
\hline Fusariella obstipa & Roots of Rhizophora mucronata & India & Ananda and Sridhar 2002 \\
\hline Fusarium & Roots of Acanthus ihcifolius & India & Ananda and Sridhar 2002 \\
\hline
\end{tabular}


chlamydosporum

\begin{tabular}{|c|c|c|c|}
\hline Fusarium oxysporum & $\begin{array}{l}\text { Roots of Acanthus ihcifolius, Avicennia } \\
\text { officinalis, Rhizophora mucronata }\end{array}$ & India & Ananda and Sridhar 2002 \\
\hline Fusarium sp. & Leaves of Avicennia marina & India & Nayak and Anandhu 2017 \\
\hline $\begin{array}{l}\text { Fusicoccum } \\
\text { microsporum }\end{array}$ & Leaves of Terminalia catappa & $\begin{array}{l}\text { Dominican } \\
\text { Republic }\end{array}$ & Hariot and Karsten 1890 \\
\hline $\begin{array}{l}\text { Ganoderma } \\
\text { pulverulentum }\end{array}$ & Dry trunk of Hippomane mancinellae & Grenada & Murrill 1908 \\
\hline $\begin{array}{l}\text { Gloeosporium } \\
\text { barringtoniae }\end{array}$ & Leaves of Barringtonia asiaticae & Hawaii & Poonyth et al. 2000 \\
\hline $\begin{array}{l}\text { Gloeosporium hibisci- } \\
\text { tiliacei }\end{array}$ & Living leaves of Hibiscus tiliaceus & $\begin{array}{l}\text { Republic of } \\
\text { Formosa }\end{array}$ & Sawada 1931 \\
\hline Gloeosporium inocarpi & Fruits of Inocarpus fagifer & Singapore & Saccardo 1918 \\
\hline $\begin{array}{l}\text { Gloeosporium } \\
\text { terminaliae }\end{array}$ & Leaves of Terminalia catappa & Burma & Sydow and Butler 1916 \\
\hline Glomerella sp. & Living leaves of Avicennia marina & $\begin{array}{l}\text { Hong Kong, } \\
\text { India }\end{array}$ & $\begin{array}{l}\text { Poonyth et al. 2000, Suryanarayanan et } \\
\text { al. 1998, Nayak and Anandhu } 2017\end{array}$ \\
\hline Gnomoniella hibisci & On Hibiscus tiliaceus & Taiwan & Sawada 1942 \\
\hline Guignardia sp. & $\begin{array}{l}\text { Leaves of Acanthus ilicifolius var. } \\
\text { xiamenensis, Lumnitzera racemosa, } \\
\text { Rhizophora mangle }\end{array}$ & $\begin{array}{l}\text { Brazil, } \\
\text { Taiwan }\end{array}$ & $\begin{array}{l}\text { Costa et al. 2012, Wei-Chiung Chi et al. } \\
2019\end{array}$ \\
\hline Hansfordia pulvinata & Roots of Rhizophora mucronata & India & Ananda and Sridhar 2002 \\
\hline $\begin{array}{l}\text { Haplosporella } \\
\text { thespesiae }\end{array}$ & Leaves of Thespesia populnea & $\begin{array}{l}\text { Dominican } \\
\text { Republic }\end{array}$ & Poonyth et al. 2000 \\
\hline Harknessia terminaliae & Leaves of Terminalia catappa & Taiwan & Sawada 1959 \\
\hline $\begin{array}{l}\text { Helminthosporium } \\
\text { glabroides }\end{array}$ & On Laguricularia racemosa & & Seymour 1929 \\
\hline $\begin{array}{l}\text { Helminthosporium } \\
\text { subsimile }\end{array}$ & $\begin{array}{l}\text { Living and dead leaves of Bruguiero } \\
\text { hoinesii }\end{array}$ & Singapore & Saccardo 1918 \\
\hline Helotium inocarpi & Leaves of Inocarpus fagifer & New Guinea & Hennings $x x x x$ \\
\hline $\begin{array}{l}\text { Hemidothis } \\
\text { pellitiformis }\end{array}$ & Leaves of Thespesia populnea & $\begin{array}{l}\text { Dominican } \\
\text { Republic }\end{array}$ & Poonyth et al. 2000 \\
\hline Hendersonia sp. & Leaves of Terminalia catappa & Philippines & Petrak 1928 \\
\hline Heterosporium terrestre & $\begin{array}{l}\text { Roots of Rhizophora mucronata, } \\
\text { Sonneratia caseolans }\end{array}$ & India & Ananda and Sridhar 2002 \\
\hline Hortaea werneckii & $\begin{array}{l}\text { Leaves of Acanthus ilicifolius var. } \\
\text { xiamenensis }\end{array}$ & Taiwan & Wei-Chiung Chi et al. 2019 \\
\hline Humicola alopallonella & Roots of Rhizophora mucronata & India & Ananda and Sridhar 2002 \\
\hline Hydea pygmea & Roots of Rhizophora mucronata & India & Ananda and Sridhar 2002 \\
\hline $\begin{array}{l}\text { Hyphoderma } \\
\text { scaevolae }\end{array}$ & On Scaevola taccada & Reunion & Boidin and Gilles 1991 \\
\hline Hyphodontia aloha & Dead branches of Hibiscus tiliaceus & Hawaii & Gilbertson and Adaskaveg 1993 \\
\hline Inonotus cremeicinctus & Trunk of Avicennia sp. & Singapore & Corner 1991 \\
\hline Irenopsis coronata & Leaves on Hibiscus tiliaceus & Puerto Rico & Stevens 1916 \\
\hline Irenopsis moelleriana & Leaves of Hibiscus tiliaceus & Puerto Rico & Hansford 1957 \\
\hline
\end{tabular}




\begin{tabular}{|c|c|c|c|}
\hline $\begin{array}{l}\text { Kyphophora } \\
\text { avicenniae }\end{array}$ & Leaves of Avicennia marina & Austrailia & Sutton 1991 \\
\hline Lasiodiplodia citricola & $\begin{array}{l}\text { Dead branches of standing Rhizophora } \\
\text { apiculata }\end{array}$ & Thailand & This study \\
\hline Lasiodiplodia sp. & Branch die-back of Avicennia marina & South Africa & Osorio et al. 2017 \\
\hline $\begin{array}{l}\text { Lasiodiplodia } \\
\text { theobromae }\end{array}$ & On Hibiscus tiliaceus & - & Pole-Evans 1905 \\
\hline $\begin{array}{l}\text { Leptothyrium } \\
\text { rhizophorae }\end{array}$ & Leaves of Rhizophora mangle & $\begin{array}{l}\text { Dominican } \\
\text { Republic }\end{array}$ & Gonzalez Fragoso and Ciferri 1928 \\
\hline $\begin{array}{l}\text { Lichtheimia } \\
\text { corymbifera }\end{array}$ & Leaves of Rhizophora mucronata & Pakistan & Tariq et al. 2006 \\
\hline $\begin{array}{l}\text { Linocarpon } \\
\text { angustatum }\end{array}$ & Petioles of Nypa fruticans & Malaysia & Hyde and Alias 1999 \\
\hline $\begin{array}{l}\text { Linocarpon } \\
\text { appendiculatum }\end{array}$ & Fronds of Nypa fruticans & Brunei & Hyde 1988, 1992 \\
\hline Linocarpon livistonae & Fronds of Nypa fruticans & Brunei & Hyde and Sarma 2006 \\
\hline Linocarpon nipae & Fronds of Nypa fruticans & Brunei & Hyde and Sarma 2006 \\
\hline Mapea radiata & Fruits of Inocarpus fagifer & $\begin{array}{l}\text { French } \\
\text { Polynesia }\end{array}$ & Patouillard 1906 \\
\hline Meliola ceriopis & Living leaves of Ceriojas tagal & Brunei & Poonyth 2000 \\
\hline Meliola cylindrophora & Living leaves of Caesalpinia crista & Philippines & Rehm 1913 \\
\hline Meliola elodea & Leaves of Ceriojas tagal & Brunei & Sydow. 1928 \\
\hline Meliola hippomaneae & $\begin{array}{l}\text { Living leaves of Hippomane } \\
\text { mancinellae }\end{array}$ & Panama & Stevens 1928 \\
\hline Meliola procera & On Hibiscus tiliaceus & $\begin{array}{l}\text { Dominican } \\
\text { Republic }\end{array}$ & Poonyth et al. 2000 \\
\hline $\begin{array}{l}\text { Micropeltis } \\
\text { lagunculariae }\end{array}$ & Leaves of Laguricularia racemosa & & Seymour 1929 \\
\hline Mollisia petiolorum & On Hibiscus tiliaceus & Hawaii & Cash 1938 \\
\hline Mycosphaerella devia & Living leaves of Dalbergia ecastophylla & $\begin{array}{l}\text { Dominican } \\
\text { Republic }\end{array}$ & Poonyth et al. 2000 \\
\hline $\begin{array}{l}\text { Mycosphaerella } \\
\text { pongamiae }\end{array}$ & Leaves of Pongamia pinnata & $\begin{array}{l}\text { Indonesia, } \\
\text { Taiwan }\end{array}$ & Raciborski 1900 \\
\hline Mycosphaerella sp. & Leaf galls of Avicennia marina & South Africa & Osorio et al. 2017 \\
\hline $\begin{array}{l}\text { Myxotrichum } \\
\text { chartarum }\end{array}$ & Roots of Rhizophora mucronata & India & Ananda and Sridhar 2002 \\
\hline Neocosmospora solani & Leaves of Rhizophora mucronata & Pakistan & Tariq et al. 2006 \\
\hline Neodevriesia capensis & $\begin{array}{l}\text { Leaves of Acanthus ilicifolius var. } \\
\text { xiamenensis }\end{array}$ & Taiwan & Wei-Chiung Chi et al. 2019 \\
\hline Neofusicoccum ribis & $\begin{array}{l}\text { On Hibiscus tiliaceus, Laguricularia } \\
\text { racemosa }\end{array}$ & - & Shear et al. 1924, Seymour 1929 \\
\hline $\begin{array}{l}\text { Neolinocarpon } \\
\text { globosicarpum }\end{array}$ & Fronds of Nypa fruticans & Brunei & Hyde and Sarma 2006 \\
\hline $\begin{array}{l}\text { Neolinocarpon } \\
\text { nypicola }\end{array}$ & Rachid of Nypa fruticans & Malaysia & Hyde and Alias 1999 \\
\hline
\end{tabular}




\begin{tabular}{|c|c|c|c|}
\hline $\begin{array}{l}\text { Neopestalotiopsis } \\
\text { acrostichi }\end{array}$ & leaf spots of Acrostichum aureum & Thailand & Norphanphoun et al. 2019 \\
\hline $\begin{array}{l}\text { Neopestalotiopsis } \\
\text { alpapicalis }\end{array}$ & Leaves of Nypa fruticans & Thailand & Kumar et al. 2019a \\
\hline $\begin{array}{l}\text { Neopestalotiopsis } \\
\text { brachiata }\end{array}$ & leaf spots of Rhizophora apiculata & Thailand & Norphanphoun et al. 2019 \\
\hline $\begin{array}{l}\text { Neopestalotiopsis } \\
\text { petila }\end{array}$ & leaf spots of Rhizophora mucronata & Thailand & Norphanphoun et al. 2019 \\
\hline $\begin{array}{l}\text { Neopestalotiopsis } \\
\text { rhizophorae }\end{array}$ & leaf spots of Rhizophora mucronata & Thailand & Norphanphoun et al. 2019 \\
\hline $\begin{array}{l}\text { Neopestalotiopsis } \\
\text { sonneratae }\end{array}$ & leaf spots of Sonneratia alba & Thailand & Norphanphoun et al. 2019 \\
\hline $\begin{array}{l}\text { Neopestalotiopsis } \\
\text { thailandica }\end{array}$ & leaf spots of Rhizophora mucronata & Thailand & Norphanphoun et al. 2019 \\
\hline Nigrospora oryzae & Roots of Rhizophora mucronata & India & Ananda and Sridhar 2002 \\
\hline Nigrospora oryzae & $\begin{array}{l}\text { Leaves of Acanthus ilicifolius var. } \\
\text { xiamenensis }\end{array}$ & Taiwan & Wei-Chiung Chi et al. 2019 \\
\hline Nodulisporium sp. & $\begin{array}{l}\text { Leaves of Acanthus ilicifolius var. } \\
\text { xiamenensis }\end{array}$ & Taiwan & Wei-Chiung Chi et al. 2019 \\
\hline Ophiostoma ulmi & Roots of Rhizophora mucronata & India & Ananda and Sridhar 2002 \\
\hline Oxydothis nypae & Fronds of Nypa fruticans & Brunei & Hyde and Sarma 2006 \\
\hline $\begin{array}{l}\text { Pachytrype } \\
\text { graphidioides }\end{array}$ & Dead wood of Terminalia catappa & Philippines & Sydow and Sydow 1914 \\
\hline Paecilomyces variotii & Roots of Rhizophora mucronata & India & Ananda and Sridhar 2002 \\
\hline $\begin{array}{l}\text { Passalora } \\
\text { pongamiicola }\end{array}$ & On Pongamia pinnata & India & Kar and Mandal 1969 \\
\hline $\begin{array}{l}\text { Passalora } \\
\text { pongamiicola }\end{array}$ & On Calophyllum inophyllum & India & Poonyth et al. 2000 \\
\hline Patellaria atrata & On Hibiscus tiliaceus & - & Cash 1938 \\
\hline $\begin{array}{l}\text { Penicillium } \\
\text { chrysogenum }\end{array}$ & Leaves of Avicennia marina & India & Nayak and Anandhu 2017 \\
\hline Penicillium citrinum & Leaves of Avicennia marina & India & Nayak and Anandhu 2017 \\
\hline Penicillium dierckxii & Phylloplane of Avicennia marina & India & Nayak and Anandhu 2017 \\
\hline Penicillium digitatum & Leaves of Avicennia marina & India & Nayak and Anandhu 2017 \\
\hline Penicillium oxalicum & Leaves of Avicennia marina & India & Nayak and Anandhu 2017 \\
\hline Peniophorella rude & On Hibiscus tiliaceus & Hawaii & Gilbertson and Adaskaveg 1993 \\
\hline Pestaliopsis sp. & On Pongamia pinnata & $\begin{array}{l}\text { Philippines, } \\
\text { India, Hong } \\
\text { Kong }\end{array}$ & $\begin{array}{l}\text { Alias et al. 1999, Suryanarayanan et al. } \\
1998\end{array}$ \\
\hline $\begin{array}{l}\text { Pestalotiopsis } \\
\text { agallochae }\end{array}$ & $\begin{array}{l}\text { Endophyte of Excoecaria agallocha, } \\
\text { Rhizophora apiculata, Rhizophora } \\
\text { mucronata, phragmities autralis }\end{array}$ & India & Poonyth et al. 2000 \\
\hline $\begin{array}{l}\text { Pestalotiopsis } \\
\text { microspora }\end{array}$ & $\begin{array}{l}\text { Leaves of Acanthus ilicifolius var. } \\
\text { xiamenensis }\end{array}$ & Taiwan & Wei-Chiung Chi et al. 2019 \\
\hline $\begin{array}{l}\text { Pestalotiopsis } \\
\text { rhizophorae }\end{array}$ & leaf spots of Rhizophora apiculata & Thailand & Norphanphoun et al. 2019 \\
\hline
\end{tabular}




\begin{tabular}{|c|c|c|c|}
\hline $\begin{array}{l}\text { Pestalotiopsis } \\
\text { thailandica }\end{array}$ & leaf spots of Rhizophora apiculata & Thailand & Norphanphoun et al. 2019 \\
\hline Petriella sordida & Roots of Avicennia officinalis & India & Ananda and Sridhar 2002 \\
\hline $\begin{array}{l}\text { Phaeophleospora } \\
\text { eucalypticola }\end{array}$ & $\begin{array}{l}\text { Leaves of Acanthus ilicifolius var. } \\
\text { xiamenensis }\end{array}$ & Taiwan & Wei-Chiung Chi et al. 2019 \\
\hline $\begin{array}{l}\text { Phaeosphaeria } \\
\text { phoenicicola }\end{array}$ & $\begin{array}{l}\text { Leaves of Acanthus ilicifolius var. } \\
\text { xiamenensis }\end{array}$ & Taiwan & Wei-Chiung Chi et al. 2019 \\
\hline Phanerina mellea & $\begin{array}{l}\text { Leaves of Acanthus ilicifolius var. } \\
\text { xiamenensis }\end{array}$ & Taiwan & Wei-Chiung Chi et al. 2019 \\
\hline Phellinus gilvus & & & Kohlmeyer 1969 \\
\hline Phellinus gilvus & Dead wood of Calophyllum inophyllum & Philippines & Murrill 1908 \\
\hline Phellinus terminaliae & On Terminalia catappa & Japan & Ito and Imai 1940 \\
\hline Phoma herbarum & Roots of Rhizophora mucronata & India & Ananda and Sridhar 2002 \\
\hline Phoma rhizophorae & Dead branch of Rhizophora mangle & West Africa & Tassi 1899 \\
\hline Phoma sp. & $\begin{array}{l}\text { Leaves of Acanthus ilicifolius var. } \\
\text { xiamenensis }\end{array}$ & Taiwan & Wei-Chiung Chi et al. 2019 \\
\hline Phomopsis asparagi & $\begin{array}{l}\text { Leaves of Acanthus ilicifolius var. } \\
\text { xiamenensis }\end{array}$ & Taiwan & Wei-Chiung Chi et al. 2019 \\
\hline Phomopsis longicolla & $\begin{array}{l}\text { Leaves of Acanthus ilicifolius var. } \\
\text { xiamenensis }\end{array}$ & Taiwan & Wei-Chiung Chi et al. 2019 \\
\hline Phomopsis phaseoli & $\begin{array}{l}\text { Leaves of Acanthus ilicifolius var. } \\
\text { xiamenensis }\end{array}$ & Taiwan & Wei-Chiung Chi et al. 2019 \\
\hline Phomopsis pittospori & $\begin{array}{l}\text { Roots of Avicennia officinalis, } \\
\text { Rhizophora mucronata }\end{array}$ & India & Ananda and Sridhar 2002 \\
\hline $\begin{array}{l}\text { Phomopsis } \\
\text { rhizophorae }\end{array}$ & & Brazil & Batista et al. 1955 \\
\hline Phomopsis sp. & $\begin{array}{l}\text { Leaves of Acanthus ilicifolius var. } \\
\text { xiamenensis }\end{array}$ & Taiwan & Wei-Chiung Chi et al. 2019 \\
\hline Phomopsis terminaliae & Leaves of Terminalia catappa & $\begin{array}{l}\text { Taiwan, } \\
\text { Brazil, and } \\
\text { Zambia }\end{array}$ & Hennings 1908, Sawada 1959 \\
\hline Phomopsis thespesiae & $\begin{array}{l}\text { Leaves of Thespesia populnea, } \\
\text { Caesalpinia bonduc }\end{array}$ & India & Padmabai Luke and Narayana 1979 \\
\hline Phragmodothis hibisci & Leaves of Hibiscus tiliaceus & Taiwan & Sawada 1959 \\
\hline Phragmostilbe linderi & Roots of Rhizophora mucronata & India & Ananda and Sridhar 2002 \\
\hline Phyllachora minuta & On Hibiscus tiliaceus & - & Hennings 1902 \\
\hline Phyllachora minuta & Leaves of Hibiscus tiliaceus & Indonesia & Raciborski 1900 \\
\hline Phyllachora yapensis & Leaves of Pongamia pinnata & Sri Lanka & Berkeley and Broome 1871 \\
\hline Phyllachora yapensis & Living leaves of Derris sp. & Hong Kong & Ho and Hyde \\
\hline Phyllosticta bonduc & Leaves of Caesalpinia bonduc & Puerto Rico & Stevens 1920 \\
\hline Phyllosticta catappae & Leaves of Terminalia catappa & Burma & Sydow 1916 \\
\hline Phyllosticta hiratsukae & Leaves of Rhizophora stylosa & Japan & Kobayashi and Onuki 1990 \\
\hline Phyllosticta latispora & Leaves of Terminalia catappa & South Africa & Poonyth et al. 2000 \\
\hline Physalospora & & Brazil & Batista et al. 1955 \\
\hline
\end{tabular}


rhizophorae

\begin{tabular}{llll}
\hline $\begin{array}{l}\text { Podosporium consors } \\
\text { Polyrhizon terminaliae }\end{array}$ & Languid of Bruguiero hoinesii & Singapore & Saccardo 1918 \\
\hline $\begin{array}{l}\text { Dead aerial leaves of Thespesia } \\
\text { populnea, Leaves of Termincilia } \\
\text { sonneratiae }\end{array}$ & Leaves of Sonneratia caseolaris & Philia & Poonyth et al. 2000 \\
\hline $\begin{array}{l}\text { Psathyrella } \\
\text { rhizophorae }\end{array}$ & Dead young Rhizophora mangle plant & Hawaii & Sydow and Petrak 1931 \\
\hline $\begin{array}{l}\text { Pseudocamarosporium } \\
\text { propinquum }\end{array}$ & $\begin{array}{l}\text { Leaves of Arthrocnemum indicum, } \\
\text { Suaeda maritima }\end{array}$ & India & $\begin{array}{l}\text { Kumaresan and Suryanarayanan 2001, } \\
\text { Kumaresan and Suryanarayan 2002, } \\
\text { Suryanarayanan and Kumaresan 2000, }\end{array}$ \\
\hline
\end{tabular}

$\begin{array}{llll}\text { Pseudocercospora } & \text { Leaves of Hibiscus tiliaceus } & \text { USA } & \text { Tracy and Earle } 1895\end{array}$

abelmoschi

$\begin{array}{lll}\text { Pseudocercospora } & \text { On Allophyllus cobbe } \quad \text { India } & \text { Kar and Mandal } 1973\end{array}$

allophylorum

$\begin{array}{llll}\begin{array}{l}\text { Pseudocercospora } \\ \text { allophylorum }\end{array} & \begin{array}{l}\text { Dead aerial leaves of Terminalia } \\ \text { catappa }\end{array} & \text { India } & \text { Poonyth et al. 2000 }\end{array}$

allophylorum catappa

$\begin{array}{llll}\text { Pseudocercospora } & \text { Leaves of Caesalpinia bonduc } & \text { Brazil } & \text { Hennings } 1904\end{array}$

bonducellae

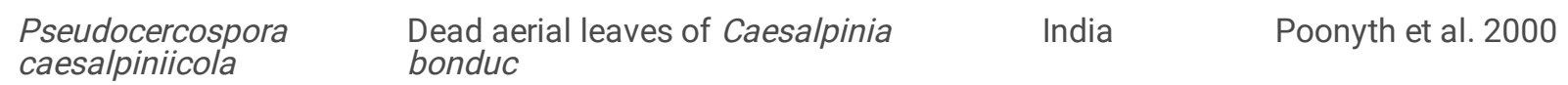

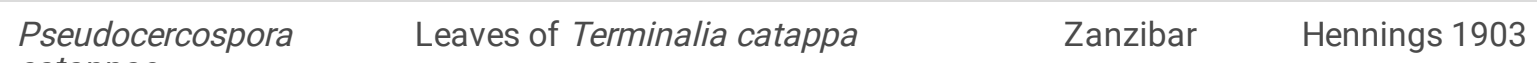

catappae

$\begin{array}{lll}\text { Pseudocercospora } & \text { Leaves of Terminalia catappa } & \text { Goh and Hsieh } 1990\end{array}$

catappae

$\begin{array}{lll}\begin{array}{l}\text { Pseudocercospora } \\ \text { hibiscina }\end{array} & \text { Leaves of Hibiscus tiliaceus } & \text { Mexico Ellis and Everhart } 1895\end{array}$

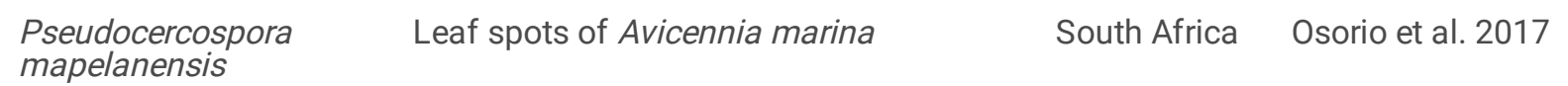

$\begin{array}{llll}\text { Pseudocercospora } & \text { Leaves of Acanthus ilicifolius var. } & \text { Taiwan } & \text { Wei-Chiung Chi et al. } 2019\end{array}$

nymphaeacea xiamenensis

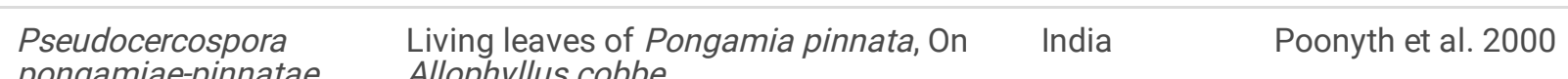

pongamiae-pinnatae Allophyllus cobbe

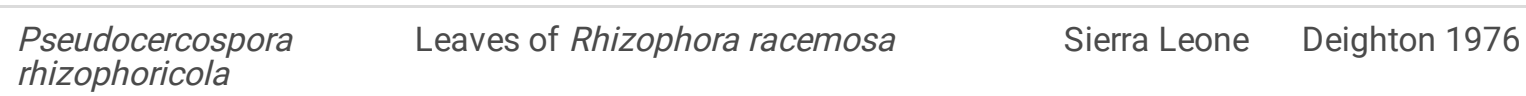

\begin{tabular}{|c|c|c|c|}
\hline Pseudocercospora sp. & $\begin{array}{l}\text { Leaves of Acanthus ilicifolius var. } \\
\text { xiamenensis, Excoecaria agallocha }\end{array}$ & $\begin{array}{l}\text { Taiwan, } \\
\text { Hong Kong }\end{array}$ & $\begin{array}{l}\text { Ho and Hyde (Unpublished), Wei-Chiung } \\
\text { Chi et al. } 2019\end{array}$ \\
\hline $\begin{array}{l}\text { Pseudoeurotium } \\
\text { zonatum }\end{array}$ & Roots of Rhizophora mucronata & India & Ananda and Sridhar 2002 \\
\hline $\begin{array}{l}\text { Pseudopestalotiopsis } \\
\text { avicenniae }\end{array}$ & Leaf spots of Avicennia marina & Thailand & Norphanphoun et al. 2019 \\
\hline $\begin{array}{l}\text { Pseudopestalotiopsis } \\
\text { curvatispora }\end{array}$ & Leaf spots of Rhizophora mucronata & Thailand & Norphanphoun et al. 2019 \\
\hline $\begin{array}{l}\text { Pseudopestalotiopsis } \\
\text { rhizophorae }\end{array}$ & Leaf spots of Rhizophora apiculata & Thailand & Norphanphoun et al. 2019 \\
\hline $\begin{array}{l}\text { Pseudopestalotiopsis } \\
\text { thailandica }\end{array}$ & leaf spots of Rhizophora mucronata & Thailand & Norphanphoun et al. 2019 \\
\hline Pterosporidium & Living leaves of Rhizophora mangle & Bermuda & Ho and Hyde 1996 \\
\hline
\end{tabular}


rhizomorphae

\begin{tabular}{|c|c|c|c|}
\hline $\begin{array}{l}\text { Pyrenophora } \\
\text { dematioidea }\end{array}$ & $\begin{array}{l}\text { Leaves of Acanthus ilicifolius var. } \\
\text { xiamenensis }\end{array}$ & Taiwan & Wei-Chiung Chi et al. 2019 \\
\hline Pyrrhoderma noxium & $\begin{array}{l}\text { Leaves of Acanthus ilicifolius var. } \\
\text { xiamenensis }\end{array}$ & Taiwan & Wei-Chiung Chi et al. 2019 \\
\hline $\begin{array}{l}\text { Ramichloridium } \\
\text { punctatum }\end{array}$ & $\begin{array}{l}\text { Leaves of Acanthus ilicifolius var. } \\
\text { xiamenensis }\end{array}$ & Taiwan & Wei-Chiung Chi et al. 2019 \\
\hline Ramularia catappae & Leaves of Terminalia catappa & Indonesia & Raciborski 1900 \\
\hline Ravenelia stictica & Leaves of Pongamia pinnata & Sri Lanka & Berkeley and Broome 1871 \\
\hline $\begin{array}{l}\text { Rhabdospora } \\
\text { phoenicis }\end{array}$ & Dry branch of Phoenix reclinata & Portugal & Poonyth et al. 2000 \\
\hline Rhizoctionia solani & Leaves of Rhizophora mucronata & Pakistan & Tariq et al. 2006 \\
\hline Rhizopus stolonifer & Leaves of Rhizophora mucronata & Pakistan & Tariq et al. 2006 \\
\hline $\begin{array}{l}\text { Rhytidhysteron } \\
\text { kirshnacephalus }\end{array}$ & $\begin{array}{l}\text { Dead branches of standing Rhizophora } \\
\text { apiculata }\end{array}$ & Thailand & This study \\
\hline $\begin{array}{l}\text { Rhytidhysteron } \\
\text { mangrovei }\end{array}$ & $\begin{array}{l}\text { Dead branches of standing Rhizophora } \\
\text { apiculata }\end{array}$ & Thailand & Kumar et al. 2019b \\
\hline $\begin{array}{l}\text { Sammeyersia } \\
\text { grandispora }\end{array}$ & $\begin{array}{l}\text { Roots of Rhizophora mucronata and } \\
\text { Sonneratia caseolans }\end{array}$ & India & Ananda and Sridhar 2002 \\
\hline Savoryella nypae & Fronds of Nypa fruticans & Brunei & Hyde and Sarma 2006 \\
\hline $\begin{array}{l}\text { Schizothyrium } \\
\text { lagunculariae }\end{array}$ & Leaves of Laguricularia racemosa & Brazil & Poonyth et al. 2000 \\
\hline $\begin{array}{l}\text { Scolecostigmina } \\
\text { palmivora }\end{array}$ & Leaves of Phoenix reclinata & - & Poonyth et al. 2000 \\
\hline $\begin{array}{l}\text { Scolecotrichum } \\
\text { barringtoniae }\end{array}$ & Leaves of Barringtonia racemosa & Madagascar & Viennot-Bourgin 1963 \\
\hline Sebacina minima & Rotting wood of Hibiscus tiliaceus & Tahiti & Olive 1958 \\
\hline Septoria thespesiae & Living leaves of Pongamia pinnata & India & Poonyth et al. 2000 \\
\hline Septoriella hubertusii & $\begin{array}{l}\text { Leaves of Acanthus ilicifolius var. } \\
\text { xiamenensis }\end{array}$ & Taiwan & Wei-Chiung Chi et al. 2019 \\
\hline $\begin{array}{l}\text { Setoseptoria } \\
\text { arundinacea }\end{array}$ & $\begin{array}{l}\text { Leaves of Acanthus ilicifolius var. } \\
\text { xiamenensis }\end{array}$ & Taiwan & Wei-Chiung Chi et al. 2019 \\
\hline Skierka agallochae & Leaves of Excoecaria agallocha & Indonesia & Raciborski 1909 \\
\hline $\begin{array}{l}\text { Sphaeronaema } \\
\text { avicenniae }\end{array}$ & Leaves of Avicennia germinans & $\begin{array}{l}\text { Dominican } \\
\text { Republic }\end{array}$ & Gonzalez Fragoso and Ciferri 1926 \\
\hline Sphaerostilbe dubia & Bark of Aegiceras corniculatum & Australia & Berkeley 1881 \\
\hline Sporormiella minima & $\begin{array}{l}\text { On Thespesia populnea, Leaves of } \\
\text { Rhizophora apiculata, Acanthus } \\
\text { ihcifolius, Avicennia marina, Avicennia } \\
\text { officinalis, Bruguiera cylindrica, Ceriops } \\
\text { decandra, Excoecana agallocha, } \\
\text { Lummtzera racemosa, Rhizophora } \\
\text { apiculata, Rhizophora mucronata, } \\
\text { Sonneratia caseolans, Sesuvium } \\
\text { portulacastrum }\end{array}$ & India & $\begin{array}{l}\text { Kumaresan and Suryanarayanan 2001, } \\
\text { Kumaresan and Suryanarayan 2002, } \\
\text { Suryanarayanan and Kumaresan 2000, } \\
\text { Suryanaryanan et al. } 1998\end{array}$ \\
\hline $\begin{array}{l}\text { Stagonosporopsis } \\
\text { cucurbitacearum }\end{array}$ & $\begin{array}{l}\text { Leaves of Acanthus ilicifolius var. } \\
\text { xiamenensis }\end{array}$ & & Wei-Chiung Chi et al. 2019 \\
\hline Striatiguttula phoenicis & Rachits of Nypa fruticans & Thailand & This study \\
\hline
\end{tabular}




\begin{tabular}{|c|c|c|c|}
\hline Stypella grilletii & Leaves of Hibiscus tiliaceus & Tahiti & Olive 1958 \\
\hline $\begin{array}{l}\text { Syncephalastrum } \\
\text { racemosum }\end{array}$ & Endophyte and living leaves & $\begin{array}{l}\text { India, } \\
\text { Malaysia }\end{array}$ & Kuthubutheen 1984, Rai 1969 \\
\hline $\begin{array}{l}\text { Tinctoporellus } \\
\text { epimiltinus }\end{array}$ & $\begin{array}{l}\text { Leaves of Acanthus ilicifolius var. } \\
\text { xiamenensis }\end{array}$ & Taiwan & Wei-Chiung Chi et al. 2019 \\
\hline Trametes demoulinii & Dead wood of Terminalia catappa & $\begin{array}{l}\text { Papua New } \\
\text { Guinea }\end{array}$ & Castillo 1994 \\
\hline Trametes rhizophorae & $\begin{array}{l}\text { Living leaves of Rhizophora mangle, } \\
\text { Trunk of Rhizophora sp. }\end{array}$ & $\begin{array}{l}\text { Papua New } \\
\text { Guinea }\end{array}$ & Reichardt 1870, Ho and Hyde 1996 \\
\hline Trichocladium sp. & Fronds of Nypa fruticans & Brunei & Hyde and Sarma 2006 \\
\hline Trichoderma viride & Living leaves of mangrove leaves & $\begin{array}{l}\text { Hawaii, } \\
\text { Mexico, } \\
\text { Malaysia, } \\
\text { Florida } \\
\text { (USA), India }\end{array}$ & $\begin{array}{l}\text { Bremer 1995, Poonyth et al. 2000, } \\
\text { Kuthubutheen 1984, Lee et al. Lee1973, } \\
\text { Newell 1976, Rai et al. 1969, Tariq et al. } \\
2006\end{array}$ \\
\hline Tryblidaria pongamiae & $\begin{array}{l}\text { Living roots, seedlings and living leaves } \\
\text { of Avicennia germinans, Rhizophora } \\
\text { mangle, Sonneratia alba, Rhizophora } \\
\text { mangle }\end{array}$ & India & Poonyth et al. 2000, Rao 1966 \\
\hline Tulasnella bifrons & On Hibiscus tiliaceus & - & Bourdot and Galzin 1923 \\
\hline Tulasnella pacifica & Dead wood of Hibiscus tiliaceus & Tahiti & Olive 1957 \\
\hline Tulasnella violea & On Hibiscus tiliaceus & - & Bourdot and Galzin 1909 \\
\hline $\begin{array}{l}\text { Urohendersonia } \\
\text { pongamiae }\end{array}$ & Aerial dead wood of Pongamia pinnata & India & Poonyth et al. 2000 \\
\hline Verticillium calophylli & On Calophyllum inophyllum & Mauritius & Wiehe 1949 \\
\hline Xylaria sp. & $\begin{array}{l}\text { Leaves of Acanthus ilicifolius var. } \\
\text { xiamenensis }\end{array}$ & Taiwan & Wei-Chiung Chi et al. 2019 \\
\hline Zalerion maritima & $\begin{array}{l}\text { Roots of Acanthus ihcifolius, } \\
\text { Rhizophora mucronata }\end{array}$ & India & Ananda and Sridhar 2002 \\
\hline Zasmidium citri & $\begin{array}{l}\text { Leaves of Acanthus ilicifolius var. } \\
\text { xiamenensis }\end{array}$ & Taiwan & Wei-Chiung Chi et al. 2019 \\
\hline Zygosporium masonii & $\begin{array}{l}\text { Roots of Acanthus ihcifolius, Avicennia } \\
\text { officinalis, Rhizophora mucronata }\end{array}$ & India & Ananda and Sridhar 2002 \\
\hline
\end{tabular}

\section{Figures}




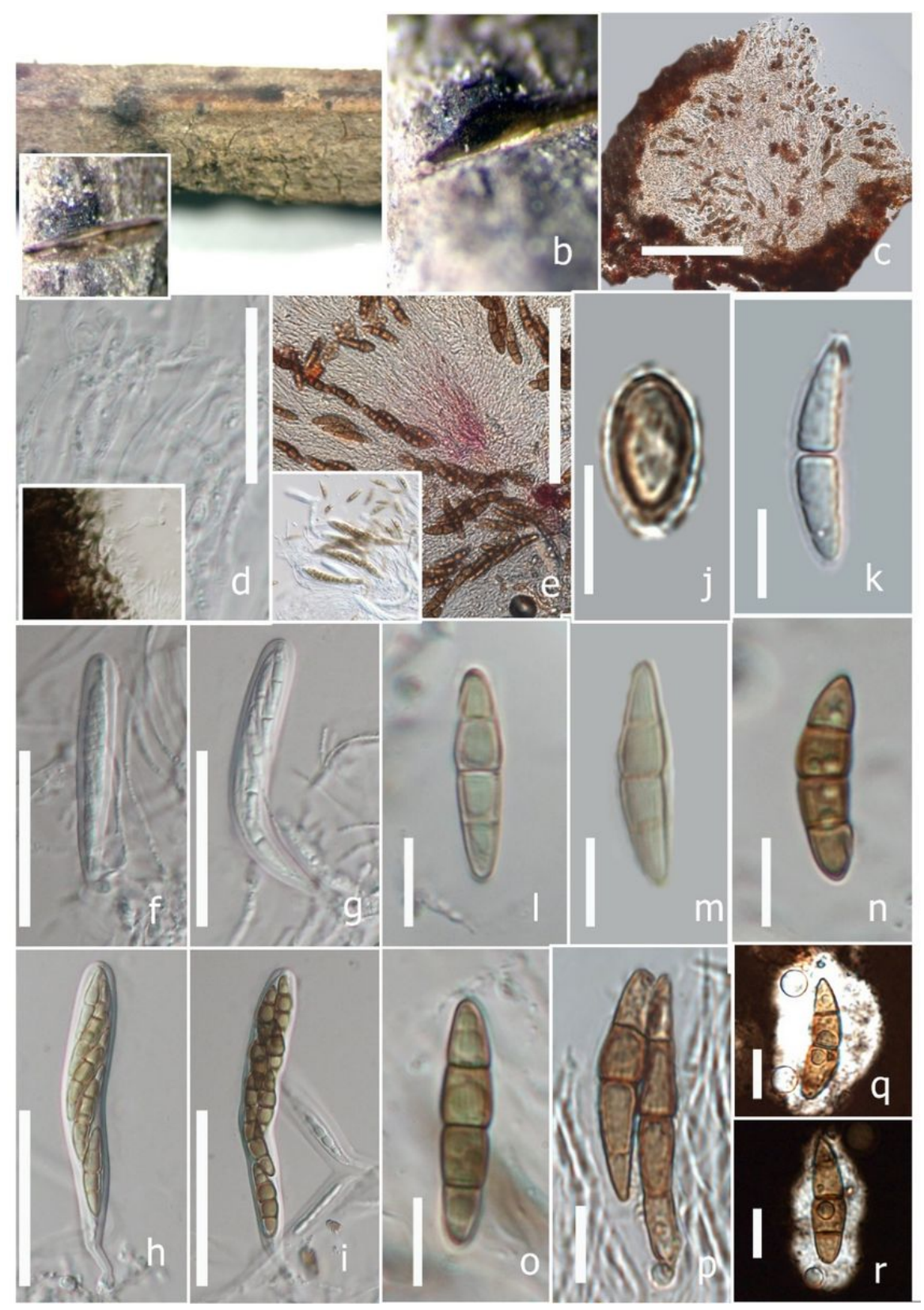

Figure 1

Striatiguttula phoenicis (Sexual morph; MFLU 19-2847). a, b Appearance of ascoma on the host surface. c Section of ascoma. d Peridium, e Hamathecium. f-i Asci. j-p Ascospores. q, $r$ Ascospore mucilaginous sheath in Indian ink. Scale bars: $c=100 \mu \mathrm{m}$, d,e $=200 \mu \mathrm{m}, \mathrm{f}-\mathrm{i}=50 \mu \mathrm{m}, \mathrm{j}-\mathrm{r}=10 \mu \mathrm{m}$. 

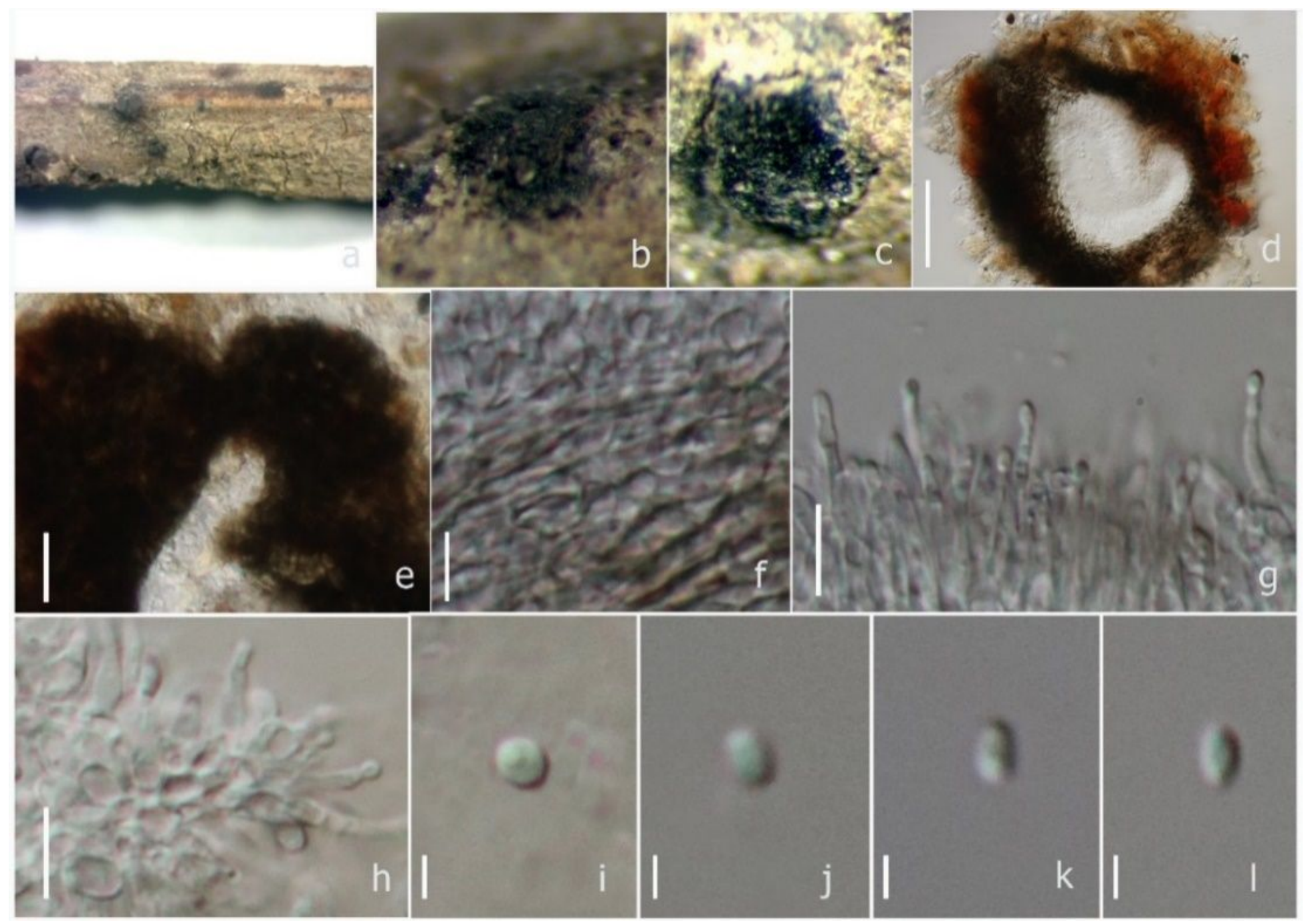

\section{Figure 2}

Striatiguttula phoenicis (asexual morph, MFLU 19-2847). a-c Appearance of conidiomata on the host surface. $d$ Vertical section of conidioma. e Apex of conidioma. $f$ Conidiomatal wall. $g$, h Conidiogenous cells and developing conidia. $\mathrm{i}-\mathrm{I}$ Conidia. Scale bars $d=100 \mu m ; e, f=50 \mu m ; g, h=20 \mu m ; i-I=5 \mu m$ 


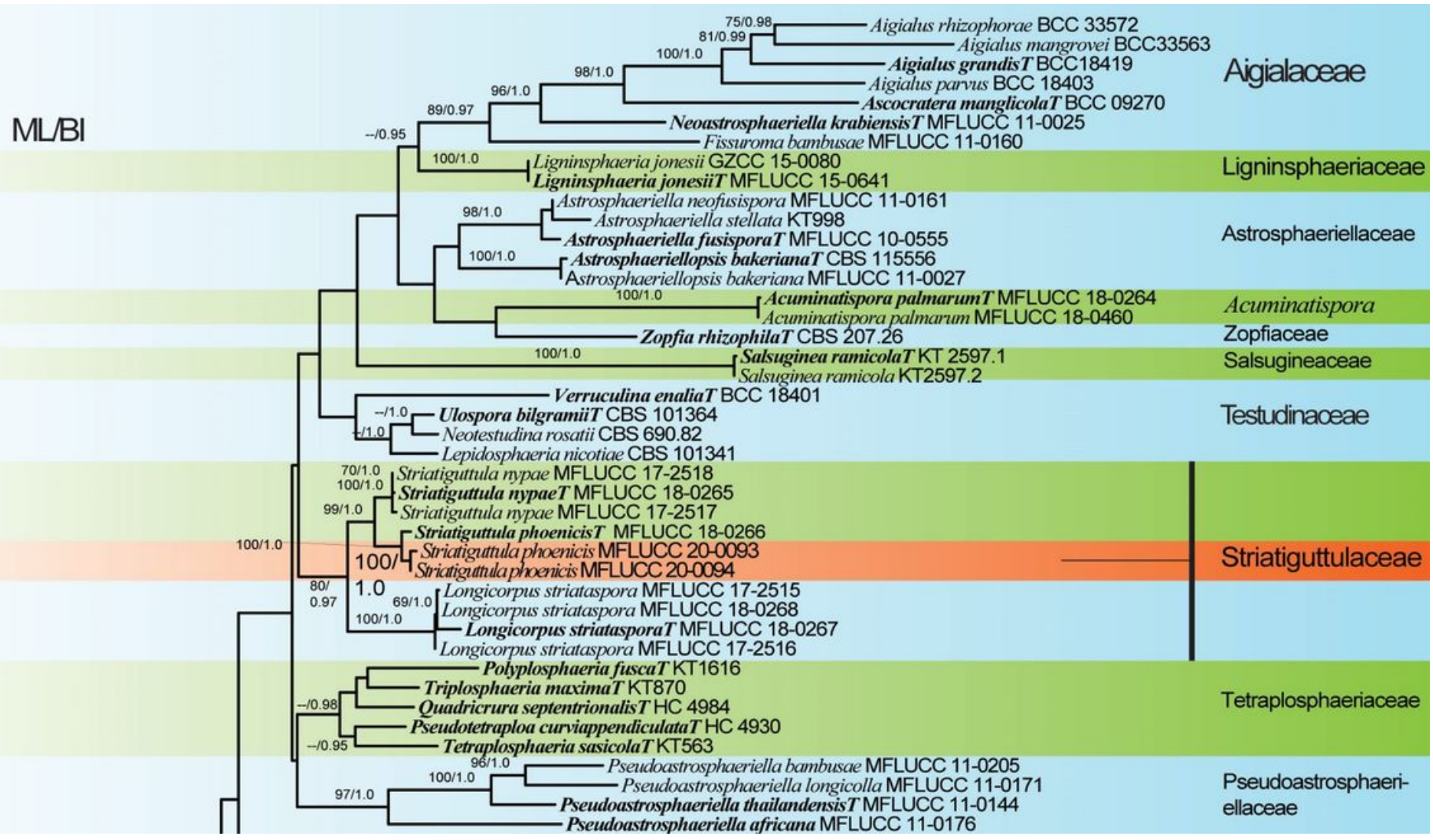

\section{Figure 3}

RAxML tree of Pleosporales based on analysis of combined LSU, SSU, and TEF1a sequence data inferred from 110 taxa and 2764 sites. The tree is artificially rooted to Arthonia dispersa (UPSC2583), Dendrographa decolorans (Ertz 5003 (BR), Lecanactis abietina (Ertz 5068 (BR), and Roccella fuciformis (Tehler 8171). Bootstrap values for ML equal to or greater than $60 \%$ and Bayesian inference equal to or greater than 0.90 are placed above and below the branches,
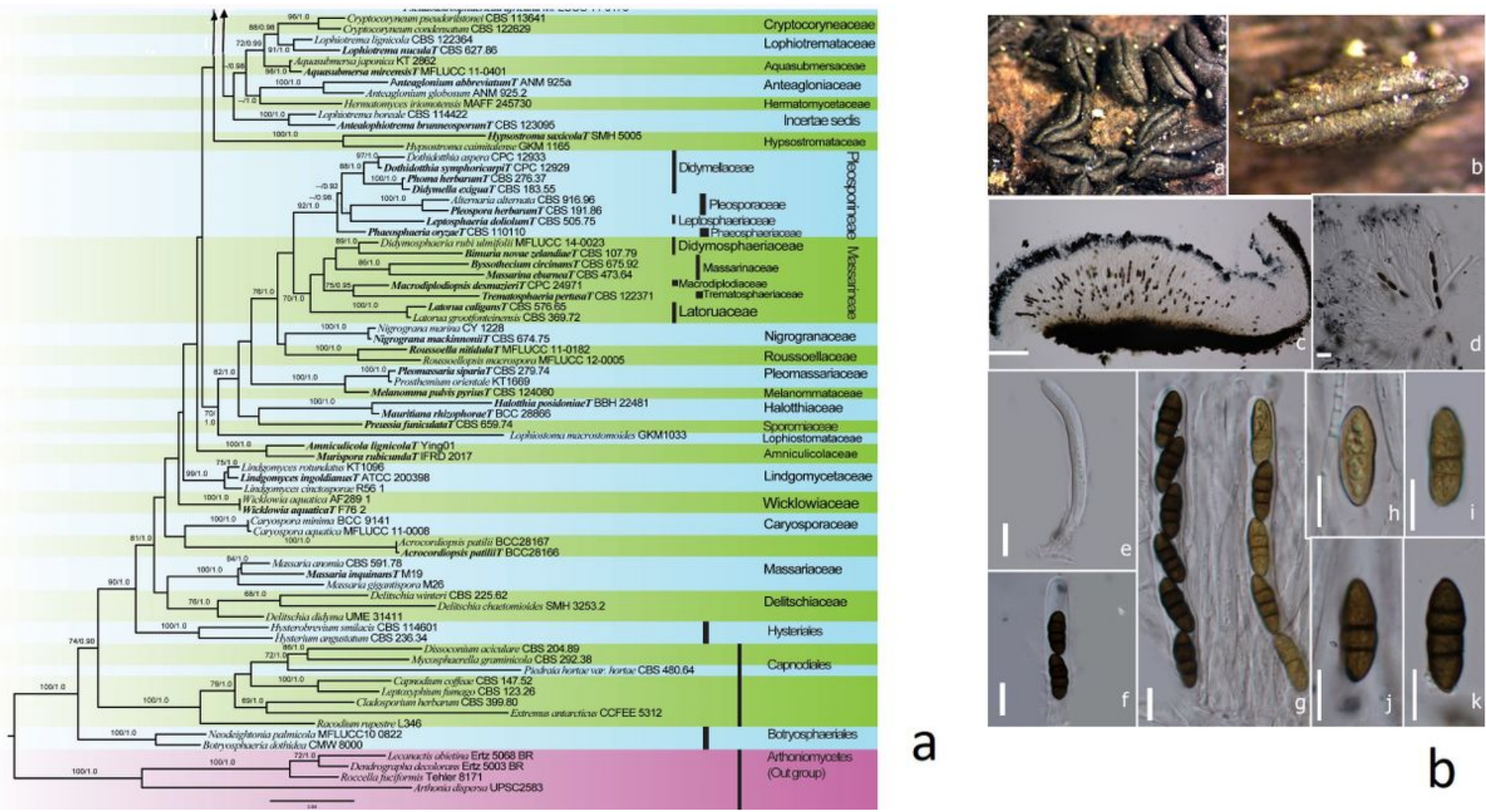
Rhytidhysteron kirshnacephalus (holotype MFLU 20-0427). a Appearance of apothecioid ascomataon the host substrate. b Close up of ascomata. c Section of ascoma. d hymenium mounted on water. e-g Asci. h-k Ascospores (h: note the ascospore with guttules). Scale bars $d=100 \mu \mathrm{m} ; \mathrm{e}-\mathrm{i}=20 \mu \mathrm{m} ; \mathrm{j}-\mathrm{p}=10 \mu \mathrm{m}$

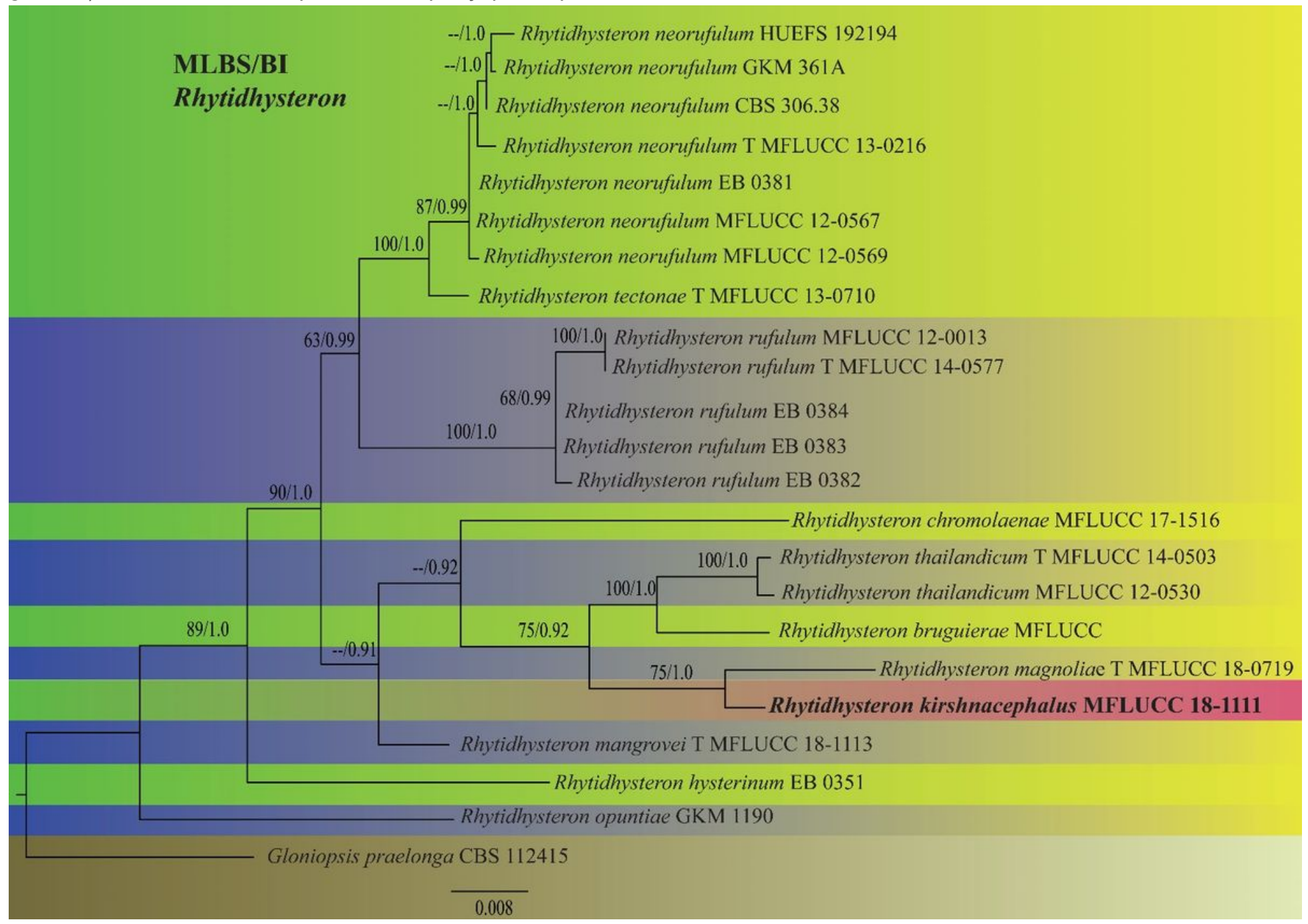

\section{Figure 5}

Maximum likelihood tree inferred from a combined SSU, LSU, ITS and TEF sequence dataset including 22 taxa from Rhytidhysteron. The tree is rooted to Gloniopsis praelonga (CBS 112415). Maximum likelihood bootstrap values (MLBS) $\geq 60 \%$ are defined as MLBS above or below the branches and Bayesian inference equal to or greater than 0.90 are placed above the branches, respectively. The new species is in black bold font 


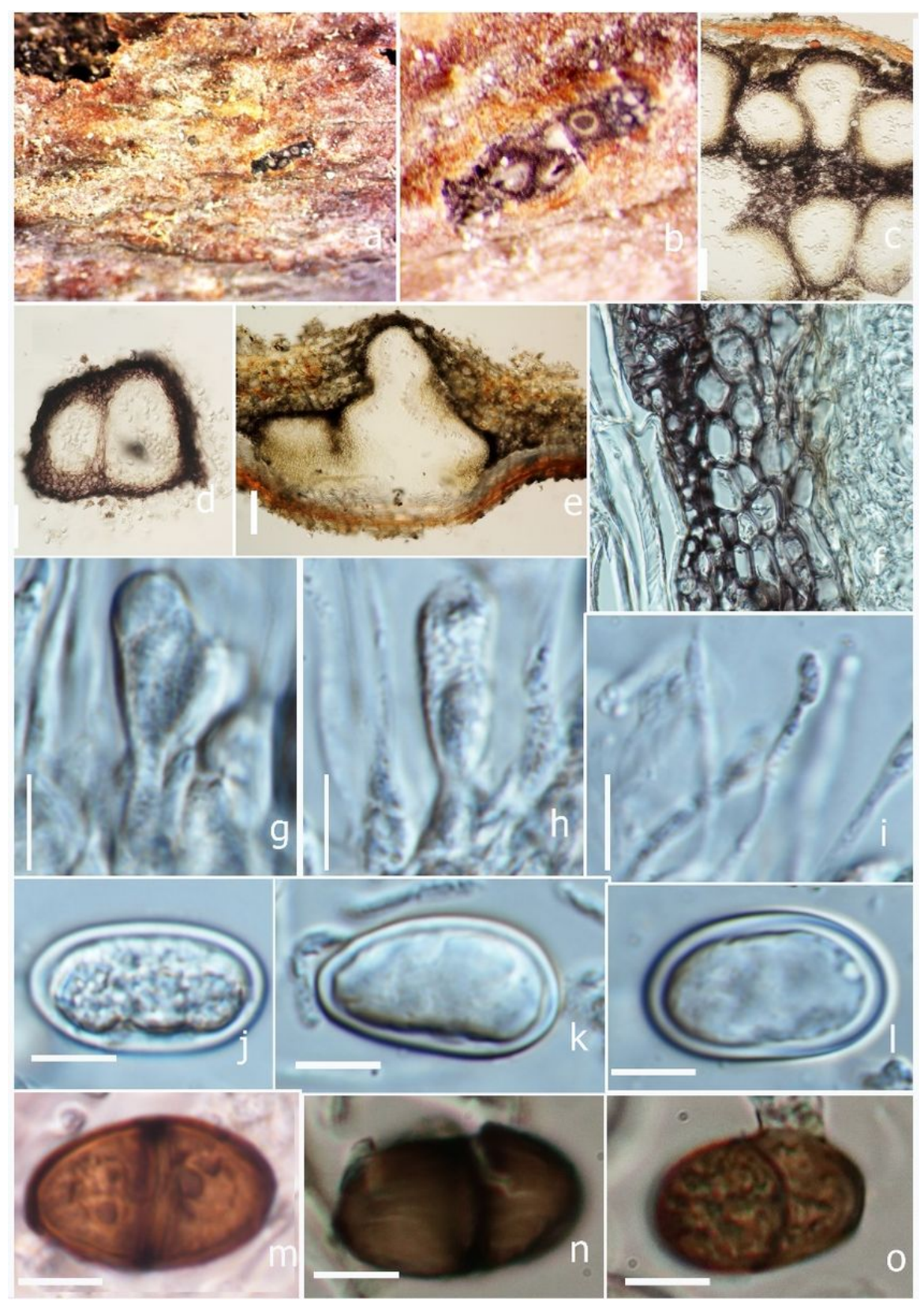

Figure 6

Lasiodiplodia citricola (MFLU 19-0622). a, b Appearance of conidiomata on host substrate. c-e Section of conidiomata. $\mathrm{f}$. Conidiomatal wall. g, h Conidiogenous cells. i Paraphyses. j-I Immature conidia. m-o Mature conidia. Scale bars: c-e $=100 \mu \mathrm{m}$; $\mathrm{g}-\mathrm{o}=10 \mu \mathrm{m}$ 


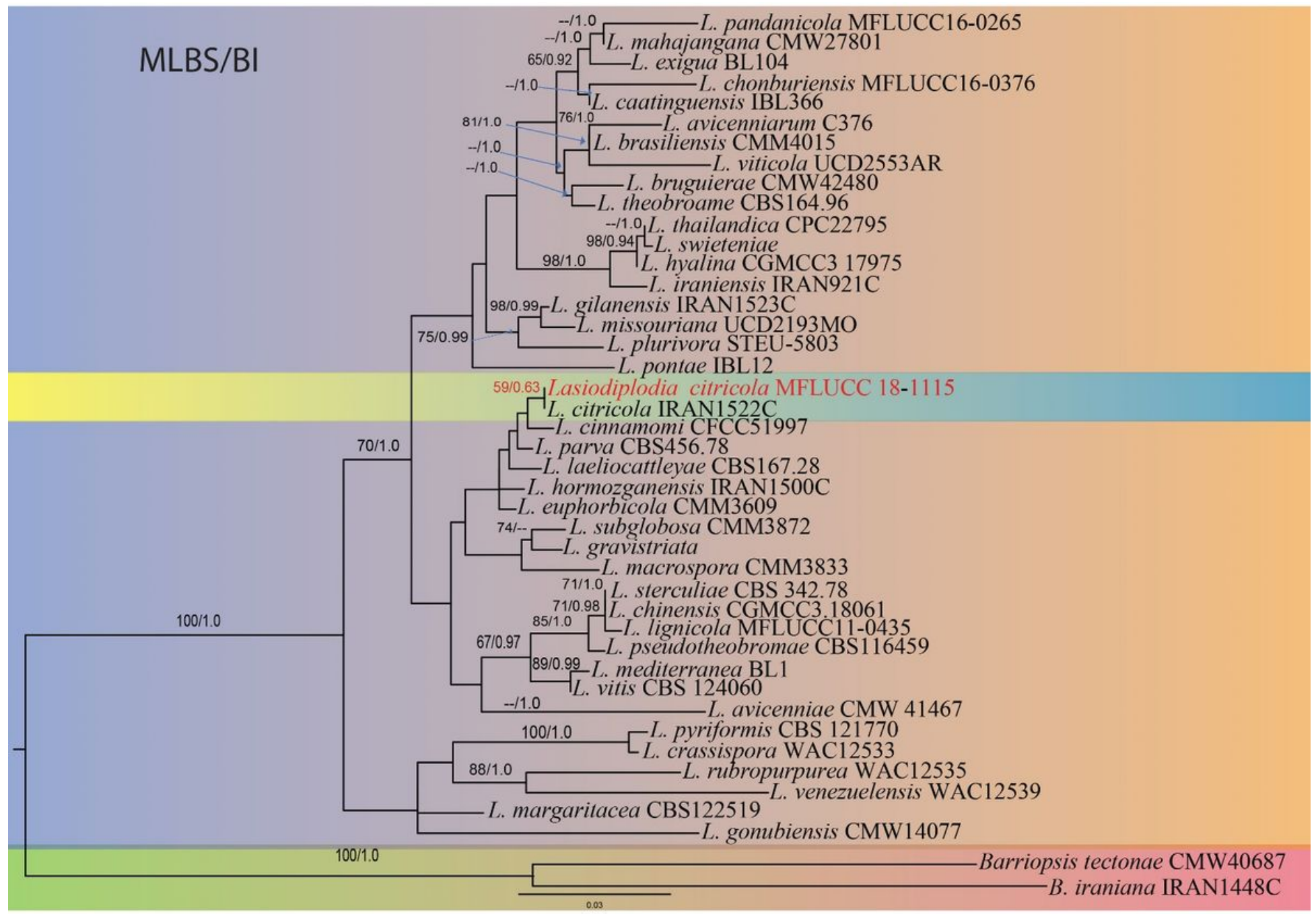

\section{Figure 7}

Maximum likelihood (ML) phylogram analysis inferred from 41 strains and a combined ITS and TEF1-a sequence data. The tree is artificially rooted to Barriopsis iraniana (IRAN1448C) and B. tectonae (CMW40687). Bootstrap values for ML equal to or greater than 65 and Bayesian posterior probabilities (BYPP) equal or greater than 0.90 are provided at the branches in that order. The new isolate is in red font 